\title{
King Rother
}

Translated by

Robert Lichtenstein 
King Rother 


\section{IIIIUNC}

From 1949 to 2004, UNC Press and the UNC Department of Germanic \& Slavic Languages and Literatures published the UNC Studies in the Germanic Languages and Literatures series. Monographs, anthologies, and critical editions in the series covered an array of topics including medieval and modern literature, theater, linguistics, philology, onomastics, and the history of ideas. Through the generous support of the National Endowment for the Humanities and the Andrew W. Mellon Foundation, books in the series have been reissued in new paperback and open access digital editions. For a complete list of books visit www.uncpress.org. 


\section{King Rother}

TRANSLATED BY ROBERT LICHTENSTEIN

UNC Studies in the Germanic Languages and Literatures Number 36 
Copyright (C) 1962

This work is licensed under a Creative Commons CC BY-NC-ND license. To view a copy of the license, visit http://creativecommons. org/licenses.

Suggested citation: Lichtenstein, Robert. King Rother. Chapel Hill: University of North Carolina Press, 1962. DoI: https://doi.org/ 10.5149/9781469657790_Lichtenstein

Library of Congress Cataloging-in-Publication Data Names: Lichtenstein, Robert.

Title: King Rother / by Robert Lichtenstein.

Other titles: University of North Carolina Studies in the Germanic Languages and Literatures; no. 36.

Description: Chapel Hill : University of North Carolina Press, [1962] Series: University of North Carolina Studies in the Germanic Languages and Literatures.

Identifiers: LCCN 63062701 | ISBN 978-o-8078-8036-4 (pbk: alk. paper) | ISBN 978-1-4696-5779-o (ebook)

Classification: LCC PD25 .N6 NO. 36 | DCC 831/.2 




\section{INTRODUCTION}

Written some time around 1160, König Rother is the oldest example in German of the secular epic, the first long narrative poem in the vernacular to have come down to us which seeks, not to instruct or to edify, but simply to entertain. Its appearance marks a turning point in the course of German literature.

During the preceding hundred years, poetry -written poetry, that is - had been completely subservient to the interests of the Church. Ever since, around 1060, the cold wind of monastic reform, emanating from the West, had begun to sweep across the German lands, clerics had been sedulously at work versifying all manner of religious materials - sermons, legends, articles of faith, paraphrases of the Bible, summonses to repentance. With little regard for the formal requirements of the medium, they had taught, admonished, and exhorted -all to the end of man's eternal redemption. In crudely built couplets they had sung of the sinfulness of the flesh, the vanity of worldly things, the overwhelming need for repentance. This earthly abode they had depicted as a brief resting-place, a temporary station on man's journey to his ultimate destination, full of snares and pitfalls, devoid of all positive values. Contempt for the world - that was the single theme on which they had rung countless changes.

Such a drastic limitation upon the scope of literature could, of course, endure only as long as the ascetic world-view of the Church went unchallenged among all classes of the population. By the middle of the twelfth century it had become clear that this was no longer the case. A new culture, with its own values and ideals, had emerged to compete with the old hieratic order for power and influence. This new culture we characterize as "courtly" because the climate most conducive to its flourishing prevailed at the courts of the great nobles. There the exponents of the new cultural values gathered, the members of the knightly class, whose social standing had recently been strengthened by their participation in the Crusades. Acknowledging the possession of God's grace as the greatest good, they were yet not disposed to forgo the pleasures and satisfactions of this world. Elegant manners, fine raiment, a handsome bearing, glory earned upon the battlefield or in the tourney, the approbation of the ladies $\rightarrow$ these stood high among the things they valued; and these were the 
things they wished to see reflected in a new kind of literature, a secular literature.

So far as we know, the first one who addressed himself to the task of writing for this new public was the author of König Rother. Realizing that, if his work were to succeed, it would have to contribute to the festive spirit of the court, he put together a story of intrigue and adventure, peopled it with doughty knights and beautiful ladies, set it against a splendid background, embellished it with lavish descriptions of material wealth, and made sure to include festivals and tournaments and the ceremonial of the court. When he was done, he had written the first tale of romantic adventure for the entertainment of a courtly audience.

Who was the author of this truly novel and significant work? The poet's name we shall never know: he chose to remain anonymous. Concerning his station in life, it was at one time popular to picture him as a Spielmann, a minstrel; only such a one, it was felt, could have written those scenes of low comedy in which the principal actors are a band of uncouth giants. On stylistic grounds, too, one thought one could detect the hand of the minstrel. Today this theory no longer convinces. The burlesque humor in which the poem abounds may well have been present already in the popular sources upon which the poet drew. And the stylistic features - the crudities and exaggerations, the stereotyped phrases and the stock epithetsare also part of that same oral tradition from which the poem sprang. (That the authors or transmitters of the oral sources of König Rother may have been minstrels is not at all improbable). Today it seems more likely that the poet's profession is more truly revealed by the pious note which, struck from time to time in the course of the poem, becomes especially loud towards the close when, having finished with his sources, he felt freer to indulge the promptings of his own spirit. In all probability, the poet was a cleric, an open-minded man who liked to listen to the stories and songs popular among the people and felt it a beguiling task to adapt such material to the taste of his noble patrons. The dialect in which he wrote, as well as references to local saints, indicate that he came from the Rhineland. That his audience was to be found among aristocratic circles in Bavaria is the conclusion to be drawn from the fact that some of the figures in his tale bear the names of noble Bavarian families.

What were the poet's sources? How much did he owe to material already at his disposal? From the evidence we have, it seems that he was familiar with two short pieces of oral poetry, two ballads, both of which were built upon the widespread motif of the abduction of a princess; and that he set to work when he saw how the two could be easily joined together to provide the outlines of a long narrative poem of the sort already popular in France. 
It is possible to reconstruct the main lines of the first ballad if we compare the version of it in König Rotber with the much shorter and simpler version which is found in that collection of heroic legends known as the Thidrekssaga. From such a comparison it seems that the original ballad went about as follows: A young king, unmarried but eager to wed, is informed of the whereabouts of a beautiful princess. At once he dispatches twelve of his men to woo her for him. The princess' father, who considers no one to be worthy of his daughter, has the envoys thrown into a dungeon. After a year has gone by without news of his men, the young king sets out with a company of his knights to rescue them; he takes along some giants too, among whom are Asprian and Widolt with the Iron Club. Arriving in the land of the unfriendly king, he gives himself out as a banished nobleman named Dietrich. Summoned into the presence of the king, he kneels at his feet and pleads to be taken into his service. While he does so, the giants carry on in such a way that the king, intimidated, reluctantly accepts his offer. Dietrich's generosity wins him great popularity among the people, and many knights flock to his side. The princess, hearing of the splendid stranger, becomes enamored of him. Dietrich brings about a meeting by sending the princess two shoes, one of gold and one of silver. When she tries them on, she finds to her dismay that they both fit the same foot. At her request Dietrich comes to her apartment with the shoes for the other foot. Kneeling before her, he reveals to her his true identity. She agrees to flee with him. But first arrangements must be made to rescue the envoys. The princess persuades her father to release them, from the dungeon for three days against Dietrich's surety. While they are at large, a tunnel is secretly built from the dungeon up to the surface of the earth. The envoys are returned to the dungeon. One night the plan of escape is carried out. The young king flees with the princess and all his men. With an army the old king rides in pursuit. In the battle that follows he is defeated. A reconciliation takes place and the young king brings his bride safely home.

So may the groundwork for the first half of the poem have appeared. What changes did the poet see fit to make? First of all, he transferred the setting to the Eastern Mediterranean. The young king, now called Rother, becomes the Roman Emperor; his residence is at Bari. The princess' father is transformed into the Byzantine Emperor Constantine. (These changes may have been suggested by a recent event. In the years $1143 / 44$ Roger II, the Norman King of Sicily, had unsuccessfully sought to bring about a marriage between his son and the daughter of the Emperor Manuel. The envoys whom he had sent to the court at Constantinople were imprisoned.) The new locale made possible the introduction of a new 
figure - Ymelot, a heathen king. He makes his entrance soon after the envoys have been returned to their dungeon. With a mighty host he invades Constantine's realm. As a result, the prisoners (who, in the original ballad, had been freed by cunning) are released by Constantine so that they may help Rother, who has offered his services in defending the realm against the infidels. At the head of his men, Rother rides forth with Constantine and his army to meet the advancing foe. By a show of great prowess Rother captures Ymelot. $\mathrm{He}$ is sent back to Constantinople ahead of the host that he may announce the good tidings. Arriving in the city, he pretends that he has been forced to flee before the victorious heathens. He persuades the princess to take refuge upon his ship, whereupon he sails away with her to Bari.

For the second half of his poem the poet has used a ballad based upon a Hebraic-Byzantine legend which had grown up around the figure of King Solomon. (This ballad was later to be expanded into the poem entitled Salman und Morolf, of which the only version we have was written around 1300.) With this ballad König Rother shares the following incidents: A minstrel in the service of a king (Pharaoh, Constantine) abducts the wife of another king (Solomon, Rother). The latter leads an expedition to win back his wife. Leaving his army just outside the town to which his wife has been taken, he proceeds into the town, disguised as a pilgrim. Stealthily he enters the palace in which his wife is being kept. $\mathrm{He}$ is discovered and condemned to death. One grants him kis last wish: that he be hanged at a spot of his own choosing. (The spot is, of course, close by the place where his men are lying in wait.) Just as the sentence is about to be executed, he blows upon his horn, whereupon his army emerges from the wood and sets him free. In the ensuing battle his persecutors are slain. There follows a scene in which he is reunited with his wife.

Into the action of this second ballad the author of König Rother has introduced a new motif - that of the returning husband. Rother steals into the palace just as his wife is about to be forced to wed the son of Ymelot. (Ymelot, who had been taken captive in the first half of the poem, has since escaped and has returned to Constantinople with a mighty army. Constantine, forced to sue for peace, has offered his daughter in marriage to Ymelot's son.) Rother makes his presence known to his wife by means of a ring. Discovered doing so, he is taken captive, whereupon the events follow as related above. In the end Constantine is compelled to throw himself upon Rother's mercy. Magnanimously Rother spares his life, then sails home once more with his wife.

Having reached this point in his story, the poet might well have stopped. Twice had Rother got the better of Constantine. The second 
time he had forced him to submit unconditionally to his might. Here, surely, was a fitting conclusion to a poem whose basic theme was the contest for supremacy between the two mightiest rulers of the Christian world. But the poet felt that two things had still to be done: first, he had to place his work in a historical context; and second, he had to end on a properly edifying note.

To achieve his first aim, he has Rother's wife give birth to a son right after she has set foot upon Roman soil for the second time. The child, christened Pippin, is destined to become the father of Charles the Great. Such a genealogical connection, establishing as it did Rother's historical legitimation, secured the poem against the charge that it was a mere tissue of lies. At the same time, it cast back upon Rother some of the radiance which emanated from the great Carolingians.

The poem comes to an end with Rother's decision to quit the throne in favor of his son Pippin and to become a monk. This should not be interpreted as the poet's gesture of appeasement to the Church. In that age it was not at all unusual for a great nobleman to retire from the world. Besides, it gave the final touch to the portrait of Rother as the ideal Christian king.

On the whole, it must be agreed that the poet has made excellent use of the opportunities for epic expansion afforded him by his sources. Scenes which in the ballads could have been only lightly sketched in, he has drawn with firmer contours, filled with local color, and enveloped with the atmosphere of real life. Here in König Rother, for the first time in German literature, something has been captured of the contemporary world. Here is the life of the court in all its pomp and splendor; here are the celebrations and the ceremonial, the fine apparel and the shining armor, the lovely ladies and the doughty knights. But here, too, is a darker side of that life. In the dungeon scenes the poet has not shunned to give a graphic picture of human misery. Truly moving is the episode in which the prisoners emerge blinking into the light of day, feeble and emaciated after their long captivity, while their relatives and friends stand around seeking to suppress any sign of emotion lest thereby they reveal their true identities. It is in such scenes that the poet has convincingly demonstrated his mastery of the epic technique.

Although the characters have been conceived as types rather than as individuals, some of them come remarkably alive: one thinks especially of the three women of the story - the sharp-tongued old queen, the resolute princess, and the enterprising lady-in-waiting. The two protagonists, Rother and Constantine, stand out in bolder relief by reason of their dramatic contrast.

Rother is the very pattern of princely excellence. Unsurpassed in wealth and power, he presides over a court that is famous for 
its splendid and decorous ways. His conduct is at all times befitting to one so highly stationed: not even in the most trying situations does he lose his composure. Prudent and resourceful, he well deserves his reputation as "the astute man." The loyalty which binds him to his followers is absolute. His generosity to those who have deserved well of him is unbounded. He has compassion for the weak and the needy. He lacks the spirit of vengefulness and strives after justice. His deepest wish is to make himself pleasing in the sight of God. He is in truth an exemplary Christian monarch.

As Rother is the rex justus, so Constantine is the rex injustus. In him have been embodied all the repugnant features of the Byzantine emperor as he was seen by the Crusaders. $\mathrm{He}$ is vain and cowardly $\mathrm{He}$ alienates his followers by his stinginess. $\mathrm{He}$ is lacking in dignity and self-control. But his greatest sin is that of superbia, pride. How, he wants to know, does anyone dare to invade his realm? And yet he proves himself unable to cope with the theat posed by the infidels. In the end he is forced to submit to Rother, to repent his ways, and to promise that henceforth he will dedicate himself to a life of good works. Rother's triumph over Constantine symbolizes the supremacy of Rome over Byzantium.

The style of König Rother shows many resemblances to that of oral poetry. The story is told in a swift and straightforward way; there are very few poetic figures, and edifying excursions occur only towards the end. The sentence structure is predominantly paratactic. Stock phrases and epithets abound. The poet lays great stress upon keeping in close contact with his audience: he addresses it directly, assures it of the truth of what it is hearing, comments upon some interesting moment in the narrative. Frequently he gives vent to his feelings in exclamations of wonder or dismay. It is this colloquial tone which is responsible for much of the fresh and spirited effect of König Rotber; and it is this tone which I have done my utmost to capture in my translation. I have tried to keep archaic and other unusual expressions to a minimum. Always I have been concerned not to depart from the normal English word order. (Inversions, which are so incompatible with a colloquial style, I have, with few exceptions, allowed only at the end of a line when it was the case of a stock epithet, as in lady fair or bero true.)

In two important ways does the style of my translation differ from that of the original. I have allowed myself much less latitude with respect to impure rhymes; and I have employed a more regular meter by avoiding the clash of two stressed syllables coming directly one upon the other. These two departures I felt it necessary to adopt in the interest of readability. Rhymes and rhythms which public taste had already rejected in the thirteenth century as being too crude and archaic would have fallen with intolerable harshness upon 
modern ears - even upon such as are accustomed to the most dissonant effects of our contemporary poets.

The verses of the translation have been numbered to facilitate comparison with the original. The text used is that of Frings and Kuhnt (Halle: Max Niemeyer Verlag, 1954), which lists the literature on König Rother starting with the year 1922. For literature up to 1922 one should consult the Frings-Kuhnt edition of that year. The interested reader will find excellent discussions of the poem in the standard histories of Ehrismann, Fr. Vogt, Schwietering, $\mathrm{H}$. Schneider, and de Boor. 



\section{KING ROTHER}

Upon the shore of the Western Sea

There lived a lord of high degree.

Rother was the hero's name,

And he resided rich in fame

5 There at Bari in the town.

Before him other lords knelt down,

Princes seventy-and-two,

Honorable men and true:

To him was subject all their land.

$10 \mathrm{He}$ was the most illustrious man

Who ever sat upon the throne

And governed in the town of Rome.

Rother was a mighty king.

Splendidly went everything

15 And very decorously at his court

(If we can judge from our report),

So that he lacked nothing in his life

Except that he was without a wife.

Then the young counts all with one accord

20 Wished to hear from their noble lord

Why they should go on tilling their land

As long as he was a single man.

They held that it was only right

That if one was a worthy knight

25 And a ruler over the whole domain

And over so many a well-born thane,

Then he ought to take to himself a spouse

To be and adornment to his house,

For if he died without an heir,

30 Then they were sure to die of despair:

Whom should they then seat on the throne

To govern in the town of Rome?

Thus did the noble lord reply:

L. 1 the Western Sea - the Adriatic.

L. 5 Bari-a seaport in Apulia (southern Italy).

L. 7 seventy-and-tzwo - the use of numbers in this way is a characteristic feature of the popular epic style. 
"Very much afraid am I

35 That if a princess I did take

And it turned out to be a mistake,

Then I would have to pay with my head.

A well-born maiden I'd gladly wed,

A lady of such high degree

40 That she might suit a king like me

And over my proudest dukes might reign.

But I don't know of one in my whole domain

Who pleases me so fully

That you could praise her truly."

45 Now a count was among his retinue

Who helped him with his counsel true

So that much glory came to him:

Thus did he serve his sovereign.

(Into dire distress he later came.)

50 Lupold was the hero's name,

And at Rother's court he had been raised

With the greatest care in his younger days.

He was his vassal and his kin,

And for counsel Rother turned to him.

55 Never did a truer man

Serve the king of the Roman land.

From the midst of all the people then

There came together the worthiest men -

Noble lords both old and wise.

60 Honor above all they did prize,

And to decorum they paid heed.

Upon a maiden they agreed.

Lupold spoke the first of all.

"By our Redeemer, I recall

65 That in the East across the sea

A great king's daughter lives splendidly

In Constantinople Town,

The citadel of great renown.

Constantine is the ruler there.

70 His daughter is a maiden fair.

From her retinue she shines afar

As from the heavens the morning star.

She surpasses every other maid

As gold surpasses silk brocade.

75 She is so slender in the waist

That by her no lord would be disgraced.

And so lofty is her pedigree

That delighted by her a king might be. 
One waits upon her constantly.

80 But this I swear by Almighty God,

To win her will be no easy job,

For whoever has tried to make her his wife

Has had to pay for it with his life!"

To Rother it was told anon

85 What counsel had been agreed upon.

Then he asked a count to tell him plain

(Herman was the gentleman's name)

Whom he should send across the sea

To woo him the maiden faithfully.

90 Thus did the margrave make reply:

"Upon my counsel you can rely.

Lupold, sire, is the man to go!

With all his heart he loves you so,

And he knows how things stand with the maiden fair.

95 Such is my counsel, I declare!

If you can in a friendly way

Persuade the noble lord to say

That your ambassador he will be,

He will woo you the maiden most faithfully."

100 Quickly Rother sent his men

And summoned Lupold to him then.

When he came before his sovereign,

A courteous welcome was given to him.

Up from his chair the margrave sprang

105 In accordance with his lord's command.

As soon as Lupold took his seat,

Rother politely began to speak.

"It is on account of my grievous plight

That I have sent for you, good knight.

110 I wish you to woo the maid for me

Who so wondrous fair is said to be:

Thereby you will help me enhance my name.

In truth, these gentlemen all maintain

That you are the very one to go.

115 For the sake of your honor you can't say no!"

Thus did Lupold answer him

(He dearly loved his sovereign):

"Sire, such urging need not be.

Your honor is so dear to me

120 That I pledge to do this thing for you

As faithfully as I'm able to,

And win the hand of the maiden fair -

Or else my life I will forswear. 
Now summon to the court such men

125 As you may well be able to send

In accordance with propriety

To a country far across the sea :

Eleven counts of high degree;

The twelfth one I myself shall be.

130 I wish moreover that each count bring

Twelve comely knights along with him,

All decked out in such array

That a king may receive us without dismay."

To the court King Rother summoned then

135 The proudest of his liegemen -

Princes seventy-and-two.

(They always rendered him service true.)

As soon as he had disclosed his plan,

Then up spoke many a valiant man:

140 "If you should order me, sire, to fare

To the ends of the earth, I solemnly swear

That I would very gladly go:

Homage to you we all do owe."

Then eleven counts swore to their king

145 That they would woo the maid for him.

They loved him truly, so we're told,

On account of the silver and the gold

Which he gave to them so royally.

They discharged their mission loyally.

150 As soon as their word was plighted,

Then at the court was knighted

A count (Erwin was his name).

Thereupon the youthful thane

Fitted out his warriors fair

155 With skins of sable and of vair.

The other nobles followed suit:

Handsomely each equipped his troop.

They mounted steeds that were snowy white.

So many envoys well-bedight

160 Were never seen in any land.

They were led by a very prudent man.

He was cherished dearly by the king,

And had never done a dishonest thing.

The ships were loaded without delay.

165 Lupold wished to sail away.

Rother bade him not to depart

And sent a man to fetch his harp.

He had devised a clever sign 
Which he was to use at a later time.

$170 \mathrm{He}$ ordered the noblemen to go And stand on deck all in a row.

Three melodies he played thereon

Which they did recognize later on.

Then to them all the good lord said:

175 "If you are ever sore bestead

And these three tunes you happen to hear,

You can be sure that I am near!"

This gladdened the heart of many a knight

Who later was in a sorry plight.

180 In song they raised their voices high

And journeyed forth beneath the sky.

Ah, how the swelling sails did gleam

As they went sailing with the stream.

The nobles journeyed from the land.

185 Rother stood upon the strand

And prayed that Almighty God above,

In token of His lasting love,

Might deign to bring the gentlemen

Safely back to the realm again.

190 "If anyone then desires my gold

I'll give it to him in amounts untold.

But if castles and land he should prefer,

So much to him will I transfer

Until he's content with what he has won -

195 How gladly I'll see that that is done!

And I shall help him defend his land

With the help of this my trusty brand."

The messengers of high degree

Journeyed far across the sea

200 To Constantinople in Greek domain.

Their vessels they did beach amain

There upon that foreign shore.

Knightly raiment each man wore,

Fashioned in identical wise.

205 Theirs was a hardy enterprise!

Lupold asked a merchant then

To watch their ships a while for them

Until from the court they should return:

A rich reward he would thereby earn.

210 In token thereof he gave him a cloak.

"For three full days," the merchant spoke,

"I'll keep an eye on your ships for you,

No matter where you wander to. 
I swear by Almighty God on high,

215 Who fashioned me to live and die,

You've given to me so royally

That I'll guard your vessels loyally!"

The nobles dressed themselves so well

(As far as I am able to tell)

220 That never before to anyone

Did so many handsome envoys come.

Their cloaks were weighted to the ground

With the finest sapphires that could be found.

Dragons of the purest gold

225 Adorned the dress of the heroes bold;

And other creatures - hart and hind,

And marvelous things of every kind-

Were wrought in gold in their attire,

All in accordance with their desire.

230 Silks and satins made more dear

The bells upon their riding-gear.

(This earned for them much praise indeed.)

To the court in splendor they did proceed.

To Constantine's court the nobles came.

235 Then their steeds were led from them amain

Ah, how the sapphires flashed their fire

Back and forth in their attire!

The worthy Erwin did not delay:

He bade his twelve men make their way

240 After him decorously.

The other lords did the same as he:

Each went at the head of his own band.

How eagerly their dress was scanned!

Then to the king came a report

245 That there was present at his court

A company of warriors fair.

Ah, how many ran to stare

Who straightway then to the ladies pressed

To tell how the strangers all were dressed.

250 The goodly queen said thereupon:

"Constantine, rise up anon

And let us welcome these strangers here.

Dearly should I like to hear

From whence these gentlemen do fare.

255 Curious raiment they do wear!

Whosoever did command

That they should journey to our land

Must be a lord of considerable might - 
If I am able to judge aright.

260 Sire, it would seem wise to me

To treat these envoys honorably.

Such an answer will not do

As you've made to so many hitherto.

Never, I think, did such a band

265 Journey so splendidly to this land.

All of them are fair to see-

Horse and rider equally!

Such a splendid troop, I ween,

In Constantine's realm was never seen."

270 To the court the Emperor hastened then And greeted politely the noblemen.

Likewise did the goodly queen:

She welcomed there with courteous mien

Every one in like degree

275 And bowed to them decorously.

There rose up then a mighty press

As everyone marveled at their dress.

The gentlemen and the ladies fair

Only wanted to stand and stare.

280 Then up spoke Herlint, an ancient dame:

"That must be indeed a strange domain

From whence these gentlemen do fare.

So many sapphires they do wear

Set in gold most splendidly!

285 If only the good Lord would decree

That we might see the nobleman

Who sent these envoys to our land!"

Then to the king did Lupold say:

"Give me your consent, I pray,

290 That I may complete without any fear

The errand which has brought me here.

Permit me, sire, to tell you true

What a mighty king proposes to you.

$\mathrm{He}$ is the handsomest man, I swear,

295 Who ever drew breath anywhere,

And he has a mighty following.

Doughty warriors serve the king.

There is great joy at my master's court.

One sees there falcons trained for sport,

300 Battle-steeds and damsels fair;

And knightly armor is also there,

Very much to my master's taste.

And so you will not be disgraced 
If to my message you lend an ear.

305 As a knight my lord is without a peer."

Constantine replied thereto:

"Now it shall be granted you,

Seeing you ask it for your sire.

Let me know what you desire.

310 You are a handsome lad indeed!

You have my permission to proceed."

Then Lupold said without more ado

(To Rother no one was more true):

"This, O King, is the word I bear:

315 My lord desires your daughter fair.

Rother is my master's name,

And he dwells in the West beyond the main.

$\mathrm{He}$ is a man of high esteem,

And he wants your daughter for his queen.

320 And should Almighty God decree

That joined together they may be,

Then never before will any wife

Have had with a man a better life."

Sadly Constantine replied

325 (Truly, he was mortified):

"Now must I rue for many a week

That I permitted you to speak.

If I could find it in my heart

To allow my daughter to depart,

330 Then with my honor it might accord

To send her to your noble lord.

But by Almighty God I vow

That you were very shrewd just now

When you got permission to speak from me-

335 Else the light of day you'd nevermore see!

For whoever would take my daughter to wife

Has had to pay for it with his life.

Now though that's not your fate this time,

You all are prisoners of mine.

340 Here in my land you must remain

And never shall see your homes again!"

Constantine had the envoys fair

Brought into a dungeon bare.

There they spent a weary time.

345 For them the sun did never shine,

Nor did the moon send down its light.

Too soon had pleasure taken flight!

Always they were wet and cold. 
Ah, their suffering can't be told!

350 Hungry were they and sore bestead;

Often they were almost dead.

They who at home had all they craved,

In the water now were forced to bathe

Which was flowing underneath them there.

355 How wretchedly did the nobles fare!

Many a man then wept aloud

To see the state of his body proud.

Within their hearts great sorrow dwelt;

To no one might they look for help.

360 And yet our gracious Lord above,

In token of His lasting love,

Saw that later they all came

Safely back to their homes again.

Hearken further to the plight

365 Of many a deserving knight!

To Master Lupold then did say

The noble Erwin in his dismay:

"Woe is me, my brother dear!

How much longer must we be here?

370 How long can our kinsmen live

Without the aid we are pledged to give?

Or tell me who will finally

Inherit all our property.

May God Almighty of His grace

375 Deliver us from this evil place!"

They all fell crosswise to the ground.

How loudly did their cries resound

As they called out unto the Lord!

How piteously they all implored!

380 How painfully their hearts did swell!

Some of them into the water fell

So that they never rose up again.

But later for the other men

There arrived a happy day

385 When to their homes they sailed away.

Constantine then bade to him

Both his vassals and his kin,

And sent them to see the objects fair

Which in the ships had been carried there.

390 Then many a damsel went apace

Along with the others to the place

Where the mighty treasure was known to be,

To see what marvels she might see. 
Now truly, one would try in vain

395 To tell all the wonders the ships contained.

The ruddy gold was stored therein,

Stretched to wire extremely thin.

Brooches were there and fingerrings,

Along with many other things

400 Which the envoys had brought for the ladies fair.

Five thousand armlets, too, were there

Which they had planned to give away

Whenever they should end their stay.

Horses' blankets and pennons gay

405 Were lying there in great array.

Elegant tents could one behold,

Artfully adorned with gold,

Given to them by their kinsmen dear

When from the country they should steer,

410 And which they had chosen for their own.

At that time had sailed across the foam

Many a lad with spirits high -

In case our story does not lie.

Now you can hear more about gold and treasure!

415 If to see great wealth was anyone's pleasure,

There was enough of it on display.

Constantine had it carried away

And given into his treasurer's care.

And he told him that he should beware

420 Lest ever there should be a lack

In case one wanted anything back.

$\mathrm{Be}$ it armor or pennons gay,

Not a thing must go astray!

And if a courser were to die,

425 Another one he must supply -

Else with his life he would have to pay.

And he bade him guard it in such a way

That if it were given back again,

Nothing should be missing then.

430 Now a year and a day had passed

Since first those warriors were cast

Into that prison beneath the ground.

Great travail the poor men found.

Never did they cease to moan.

435 And also Rother back at home

Bitterly wept both day and night

On account of so many a worthy knight.

He wrung his hands in his dismay 
And kept on thinking night and day

440 How without danger he might detect

Where the envoys were being kept.

Then all the wise old counselors came

Whose kinsmen had sailed across the main.

Many a bitter tear they shed

445 And with their gracious lord they pled

That he himself should go and see

Whether alive they still might be.

Rother sat upon a stone;

From his heart all joy had flown.

450 For three full days he neither stirred

Nor spoke to anyone a word

But kept on thinking night and day

Whether there might be some way

Of getting to that doughty band

455 Who had ventured forth at his command

To the land of Greece beyond the main.

Then he summoned Berchter, an ancient thane,

To advise him what he ought to do.

He always gave him counsel true.

460 (Seven of his sons on that trip had gone,

And he could always be counted on.)

The king said: "Berchter, counsel me

How I can come across the sea

To Constantinople with my men.

465 I swear that if it turns out then

That God has permitted Constantine

To slay those messengers of mine,

Then nevermore shall I be found

Anywhere on Roman ground

470 Until with his own life he has paid.

Ah, how wretched I have been made!"

To him said Berchter, that ancient man

(He was, in truth, a count of Meran):

"Eleven splendid sons I had.

475 The twelfth was Helfrich, a doughty lad.

He ventured forth at your command

Across the Elbe with a mighty band.

There he led his men to war.

Always he was to the fore

480 The time he slew the heathen horde

Who would not recognize our Lord.

L. 473 Meran - Dalmatia. 
In God's employ he has been slain.

His death must give us lasting pain.

Now seven sons on this trip did go

485 For whom I shall always suffer so.

From now on I must live forlorn.

Ah, would that I had never been born!

Lupold was my eldest son,

And after him did Erwin come.

490 Now though I don't mention the other five,

For these two my grief will be always alive.

Rother, lord and master dear,

To my counsel lend an ear!

Let's start a campaign without more ado

495 And slay the Greeks and the Magyars, too.

A thousand men for you I'll lead.

The loss of my sons I rue indeed!"

Then did the faithful Rother say:

"This I never can repay!

500 My father was wont to say to me

That whoever a worthy lord would be

Would be committing a grave mistake

If good advice he refused to take

Which was given to him for his own sake.

505 Now let us hasten to the court.

To all the nobles we should report

And also to each honest knight

(In this we shall only be doing right),

So that we may hear what they think of it

510 And derive from their counsel some benefit.

Supposing that there is some man

Who can work out a better plan

Than the one which we now entertain.

Ought we to set out for the Greek domain

515 Along with a mighty company

When we don't know for a certainty

Whether the envoys aren't still alive?

Perhaps grim Death could not contrive

To overcome the noblemen.

520 If we attack with an army then,

The Greeks will slay the worthy men.

Now by Almighty God on high,

Who fashioned me to live and die,

I swear that my sorrow for them is deep!"

The gentlemen both began to weep.

To him replied the ancient duke: 
"O King, though you weren't so astute, With you I still would gladly fare:

In your distress I also share.

530 Now call together, sire, your men.

Gladly would I learn from them

What they think ought to be our plan

Of spying out the Grecian land.

(That, my lord, is but good sense.)

535 Now is my suffering most intense

On account of the handsome sons I reared

Who have so strangely disappeared.

For the sake of your honor I bade them fare.

Now, dear sir, you are aware

540 As well as I am, certainly,

In what condition they may be.

Ah, may Almighty God above,

In token of His lasting love,

Allow that day to come around

545 When I may see them safe and sound!"

Then to the court King Rother hied

(The ancient duke was at his side)

And summoned those he held most dear

To counsel him what course to steer.

550 When it was told to the company

That the king would fare across the sea,

Then up rose many a worthy knight

And spoke as truly as he might.

Thereby they sought to help their lord

555 That honor might be his reward.

At once they went to discuss this thing

Before the apartment of the king.

Then they decided to advise

The king to fare in splendid guise

560 As an exiled man across the main:

His honor he thus could best retain.

Now at the court was an ancient duke

Whom their advice did by no means suit.

He said that the trip were better not made.

565 Then Berchter came to his children's aid.

"How now, you coward!" he did say;

"How dare you counsel the king this way!"

With his fist he struck him such a blow

That from his neck the blood did flow,

570 And for three weeks he was so weak

That he could neither hear nor speak. 
Then Berchter's men were heard to say

That he had behaved in a proper way:

What cause had the other to add to his woe?

575 After all, their lord had suffered so -

More than any other there -

That to do him an injury was not fair.

The duke had got the worst of it;

With a mighty blow he had been hit.

580 To Rother then the nobles pressed

To tell him what they thought was best.

Among themselves they raised the question

Whether he would approve of their suggestion.

They said: "We've hit on a scheme for you

585 Which shouldn't be too hard to do.

We don't think it wise to make a campaign.

However, if you won't refrain,

No better way can you survive

Than by crossing the sea in an exile's guise.

590 For if the Greeks should be attacked,

This you know to be a fact:

Great harm to us will they contrive.

And should the envoys be still alive,

Then they will surely be ordered slain:

595 From this the Greeks will not refrain.

Now let it be your pleasure

To bring forth gold and treasure,

Of which you have a mighty hoard

Lying in your chamber stored.

600 You're rich enough in that, I think!

Share it wisely and do not stint,

And in this way, my noble lord,

Your honor will be soon restored.

Each of us has searched his mind,

605 And better counsel we cannot find.

If with us you do not agree,

You'll never come across the sea!"

The mighty king replied to this

(Their counsel did not come amiss):

610 "You have not counseled badly.

I will obey you gladly.

You always shared in my distress.

Now this is the height of faithfulness,

That you do not abandon me

615 Now that I need you so urgently.

In truth, I have a mighty treasure. 
Now may that man know God's displeasure

Who would stint with it in any way,

No matter whither he chance to stray."

620 Then he ordered four of his men to ride

Throughout the kingdom far and wide

And spread the news to young and old

That whoever wished to win much gold

Ought to set out upon the way

625 To the court at Rome without delay:

He needed their presence for a thing

Which to an end he could not bring

Without the help of many a knight

If it were to turn out for him all right.

630 Then he sent his letter, so we hear tell,

To a land where a curious folk did dwell.

A giant (Asprian was his name)

Who to the court no longer came,

Got so excited by the news

635 That not a minute did he lose:

He set out at once for Rother's land

Together with many a curious man.

A troop of giants he led along.

They carried clubs that were awfully long.

640 Rother's invitation,

Without exaggeration,

Was spread abroad on every side.

Then noblemen began to ride.

They dressed themselves in such array

645 That they set out splendidly on their way.

Because the summons was from the court,

They had no choice but to report.

And so a mighty host he won.

In close formation they did come

650 The time that princes seventy-two

Came to Rome for the rendezvous. Now a lad most curious to behold

Came striding along the dusty road.

He was too heavy for any steed.

655 A very strange lad he seemed indeed!

A club of steel he bore along;

It measured twenty-four cubits long.

Because of it everyone had to stare.

'Twas the giant Asprian coming there!

660 As soon as Berchter espied this folk, This is the way the hero spoke: 
"Proper fellows I do see,

Doughty warriors certainly.

A splendid troop is drawing near,

665 Well-equipped with battle-gear.

Welcome them, my gracious lord,

As with your honor it may accord.

Each one has such a mighty frame!

Wherever did a king obtain

670 So many undaunted fighting-men?

Just let somebody anger them!

If he should dodge their club by luck

And with their sword they catch him up,

His life will not be worth a rap-

675 He can be very sure of that!

Now lead, $O$ Rother, if you please,

Twelve such warriors overseas

And not a man will ever dare

To lead his people against us there

680 Unless with his life he is ready to pay.

Although they live so far away,

They have shown up here at the court

Well-equipped for your support."

In the dust the giants strode along.

685 Gleaming helmets they had on

And coats of mail that shone so bright,

Made to fit them exactly right.

Clubs of steel and swords they wore;

And very long whips they also bore:

690 There where the lash was wont to be

A chain of iron one could see,

In which was many a mighty knot.

The people had but a single thought

When they espied these curious men:

695 What might they now expect of them?

Fiercely they made ready to fight,

Clad in their corselets shining bright.

Truly, they were heroes keen!

When by Berchter this was seen,

700 Not a minute did he delay:

To them he quickly made his way.

Said he: "What's the reason for this to-do?

I forbid it to every one of you!"

The doughty lads made answer then:

705

"We do not trust those gentlemen!

We'll ward them off in such a way 
That we may well survive this day!"

The duke replied: "They've come to the court

In order to lend us their support.

710 'Tis Asprian, a noble king,

Leading those giants along with him."

Rother's behavior was most polite.

He greeted the giants all alike

As well as many a worthy man

715 Who had ridden thither to his land.

Then the excellent hero let them know

Just why he needed their presence so.

Said he: "Good warriors, hearken to me!

I must set sail across the sea

720 As though I'd been banished from my domain, And shall adopt another name.

The Emperor Constantine has, I fear,

Struck off the heads of my envoys dear.

In truth, it is a year and a day

725 Since from our land they sailed away."

As soon as they had been told this thing,

They hastened then to form a ring.

Truly, they were a mighty band!

At that time wisdom adorned each man.

730 And so they quickly decided then That Berchter should rule over them

Until King Rother came back home, For he could well defend the throne. The noble duke replied thereto:

735 "I'm not the one to govern you.

If you entrust your lands to me,

Burned and plundered they will be,

Your borders violated,

Utterly devastated.

740 Choose for yourselves some other man!

In search of my sons I must leave the land.

Offer the crown to Amalger;

It will become him well, I swear!"

Then to Amalger they gave the throne

745 And the right to govern there at Rome.

This happened in a splendid ring.

(He was the lord of Tengeling.)

Rother summoned to him then

Twelve dukes (they were comely men).

L. 747 Tengeling - in Upper Bavaria. 
750 Behind each duke there marched along

Splendid knights two hundred strong,

Just as they had proudly come.

The excellent warriors every one

Stepped forth then to join the king

755 From the midst of the mighty gathering.

Behind King Asprian there went

A dozen of his regiment.

A giant was among them there

Of whom it was prudent to beware:

760 Just like a lion he went bound.

No fiercer fellow was ever found

Among the human race, I trow,

When from his chain he was let go.

If anybody got him mad,

765 His life wasn't worth a cent, begad!

He had made his way, so we hear tell,

From a country where the giants dwell

To put his valor to the test.

By threats and treatment of the best

770 He had been tamed by Asprian

So that he swore to be his man.

Widolt was the hero's name.

He was always in a savage frame.

Rother bade his vassals true

775 Ride back home without ado

And help Sir Amalger guard the land

With all the means at their command

From evil men of every sort.

Quickly then he left the court

780 And came to Bari without delay, Where there were waiting in the bay The ships in which the noble king

Together with his following

Should venture forth across the sea.

785 The vessels were loaded speedily

With precious jewels and with gold,

With silks and satins fair to behold,

And with more wealth than one can say.

One came and carried it all away

790 From the chamber of the minghty king.

In wagons one made haste to bring

Inlaid work of every sort

To the vessels lying in the port.

Then a man was led before the king 
795 Who was able to fashion many a thing So very skilfully out of gold

That it was a great pleasure to behold.

Words can't describe it in any way!

Never before the Judgment Day

800 Will there be found another man

To work such wonders with his hand.

The ships were lying in the bay

All prepared to sail away.

Rother sent then for his harp

805 And bade his men and the giants embark.

At once they shoved off from the shore;

The rigging they began to draw.

They sailed to Constantinople Town,

The citadel of great renown,

810 Lying far across the main.

Then a clever thought to Rother came.

$\mathrm{He}$ said to his entire band:

"We're sailing to a foreign land.

Ours won't be an easy task, I fear.

815 Now this is what I want you to hear!

We all must be extremely sly

In case we do not want to die.

I wish to be called by everyone,

Both the old men and the young,

820 Dieterich in the days to come.

Thus no stranger will surmise

The nature of my enterprise."

Then all of them an oath did take,

Which no one later was to break,

825 To call him Dieterich as he bade.

He was heeded in this by many a lad.

Splendidly the mighty band

Disembarked upon the strand.

The burghers then ran up to see

830 What wonderful items there might be:

The lovely wares they wished to behold.

All at once the giants bold

Started to fight upon the beach.

The townsfolk scattered out of reach.

835 Some of them were so distressed

That they outdistanced all the rest.

Then one of their number lost no time

In making his way to Constantine.

Said he: "O King, pray tell me true! 
840 Whence comes this company to you?

They've journeyed here with so much might

That no one can describe it quite."

Then to the man the queen did say:

"What can you tell us of their array?"

845 To this the burgher answered so:

"How am I supposed to know?

There were a great many of us folks

Who didn't get to inspect the boats.

Those terrible lads gave us such a scare

850 That we didn't do much looking there.

One of them lies bound to a chain,

Otherwise we'd have all been slain.

The only thing that occurs to me

About the things that one can see

855 Is that those lads have brought along

Iron clubs both big and long.

If there was anything more to see,

I cannot tell you what it might be."

The giant fettered upon the strand

860 Received from them the strict command

To tarry there beside the sea

And keep watch over their property.

Then they dressed themselves in splendid wise:

They put on caps that drew all eyes.

865 They mounted mules as white as snow

(In Greece that was a very rare show).

They led by the hand along the way

Many a courser dapple-grey,

Handsome and of sturdy frame.

870 Wound about each horse's mane

Were pretty ribbons which had been lined

With precious stones of every kind.

Whithersoever the nobles rode,

The giants in their armor strode

875 Along the way as fast as they could.

The Emperor was in a troubled mood.

He sat in council frequently

To find out who these lords might be.

One of his counselors then did say:

880 "Sire, you now will have to pay

For the way you treated those envoys fair

Whom you threw into your dungeon bare.

If these men should their masters be,

They will do to us an injury. 
885 Some of us will be made to pay

Who never were guilty in any way.

Those fellows with the clubs, I swear,

Tower so high into the air

That no one can withstand them.

890 You've played the devil with your men!"

Now it fell upon an Easter day

That Constantine with great array

Was holding court in the Hippodrome.

Many a lord stood near the throne.

895 Counts and dukes and barons fair -

All had been invited there

That they might add to his esteem.

From them the sweat began to stream:

That was on account of the fear they had

900 When the giants began to act like mad.

When Dieterich and his following

Came into the presence of the king,

They got a courteous greeting then.

The dukes advanced to welcome them.

905 Likewise did the gracious queen:

She bowed to them with courteous mien

And bade that welcome they should be;

She greeted them decorously.

Then up to Asprian two counts went.

910 To take his club was their intent.

With so much steel had it been tipped,

They could not lift or carry it.

They had no choice but to drop it down

And leave it lying on the ground.

915 Constantine sat on his throne.

Dieterich drew near alone

And knelt politely in front of him.

He said: "I've long heard tell, O King,

About your magnanimity.

920 Now my distress, alas for me,

And my misfortune are so great,

It's beyond my power to relate.

Now honor God on me poor man,

For a king has put me in his ban.

925 Rother is the hero's name,

And he sits in the West beyond the main.

So great is the power he does wield

That everyone to him must yield.

When I was banished from his domain, 
930 There no longer might I remain.

Then I knew that there was no place Where I would ever be so safe

As here among your company -

So mighty are you said to be.

935 My homage I now offer you.

Accept it from me, hero true!

I've come here seeking your charity.

Now prove your honor, sire, on me!

If you refuse the service I tender,

940 My life to Rother I must surrender."

All the while that Rother pled,

Asprian kept stamping his leg

Into the ground up to his thigh.

To Constantine there then drew nigh

945 The very wisest of his kin

Who at the court were serving him,

To counsel whether he could afford

To shelter there so many a lord.

Said he: "From Rother he's running away.

950 Here at my court he wants to stay.

He submits himself to me outright

And tells me of his grievous plight.

Now what shall we do with this exiled man?

I wish he had never come to our land!

955 And then to his men I must allude.

They seem to me extremely rude!

Their conduct is most indiscreet.

Just look at that fellow stamping his feet!

Such a lad in Hell should be

960 To keep the Devil company."

The lords advised him to care for the men

So that they might be grateful to them.

"Of Rother it's little that we know;

These men could be a terrible foe.

965 To them we should so freely give

That they may be willing to let us live."

To Dieterich he then did say

In a very overweening way:

"Some of my men have counseled me

970 To grant you hospitality.

If their advice had not been so,

How reluctantly I'd have let you go!

The stranger who at God's direction

Comes here in search of my protection 
975 Can count upon it that he'll be served Exactly as he has deserved.

But I don't esteem at all that man

Who journeys hither to my land

Only for the sake of gold.

980 Worthy man exceeding bold,

You come to us with a mighty crew;

They all pay fealty to you.

Acknowledge my authority

And the host here you yourself shall be,

985 Because it truly pleases me

That you seek my hospitality.

We thought that you had crossed the sea

To win the hand of a maiden fair

Whom I have reared with the greatest care.

990 I'd have done like Rother in that event

When he drove you into banishment.

I've got the better of him all the same!

The men who came here in his name

Are lying chained to my dungeon-floor.

995 Never will he see them more!

There were two men among them there

Such as an emperor might care

To count among his retinue.

They led here many a hero true."

1000 As soon as Asprian heard this speech, For his shield he at once began to reach, And demanded to have his battle-gear.

Said he: "Bad words one offers us here.

You do not give my lord his due;

1005 Rother sent good lads to you.

Whoever ordered them enchained,

For that may very well be blamed.

Now here in front of you we do stand.

Before your men can subdue our band,

1010 Laid out cold someone will be

(This I swear most solemnly!)

Who thought no one was as good as he -

If only my club doesn't break on me."

Quickly he stepped into the ring.

1015 Then answered him the mighty king:

"Your anger causes me some surprise;

You've not been insulted in any wise.

That little speech which I just gave

Should not upset you, hero brave. 
1020 My men have got me so drunk today

That like a fool I babble away.

That's why I shouldn't even try

To give a good lad a proper reply.

Now what I say, good sir, is true:

1025 I made that threat without meaning to,

For the wine in my head keeps going around,

And its effect is so profound

That over my tongue I have no command

When talking to your master's man."

1030 Asprian's anger passed away.

Then Dieterich's men did not delay:

They settled down so near the beach

That the vessels they could easily reach.

Quickly the stewards every one

1035 Who with Sir Dieterich had come

Procured twelve wagons all alike,

Which went full charged a sevennight.

They brought there all the treasure and gold

And whatever else the ships did hold -

1040 A very great hoard, so we hear tell.

Along went a man who guarded it well.

Six terrible giants kept driving him

And bade him raise up such a din

That all the people in the town

1045 Should never cease to spread around

Rumors about Sir Dieterich's crew.

Then he almost burst his chain in two.

He picked two rocks up from the ground

And with then he began to pound,

1050 So that great flames shot into the air.

Then the Greeks began to run from there.

Yet some chased after him all the time

Until he came before Constantine.

Then said a count for all to hear:

1055 "The Devil's bride is drawing near!

If only the shame which should be mine

Could ever be erased in time,

I swear by the Eternal Light

That I'd not wait here in the Emperor's sight!"

As soon as the goodly queen espied

The lad who to a chain was tied,

She said: "Lord Constantine, I vow

That they're leading to you your master now, Fastened to a chain, in troth! 
1065 Alas! how stupid were we both To have kept our daughter from the man Who banished these fellows from his land. Such conduct wasn't very wise. May God Almighty now chastise

1070 Your peevish disposition!

Ah, if my admonition

You had, good sir, paid heed to then,

You now could capture or slay these men.

But I bet that whatever they ask of you,

1075 Out of fear you will agree to do

And not at all because you're kind. If only they were of my mind, They'd bid you give the maid to them For whom you've slain so many men

1080 And brought so many into distress; Then I should see your cleverness!

These lads don't seem to suit you right; They number so many a doughty knight. They are too strong for you, $O$ King!

1085 Methinks you had rather dare to bring

Your hand up sharp into your eye

Than with his followers to vie

Over even a tiny pin.

Your conduct all this day has been

1090 Unworthy of a gentleman.

Your drunkenness is but a sham!"

The strangers stabled their steeds apace.

In the courtyard then they took their place.

They wrapped themselves in their mantles tight.

1095 Truly, their bearing was most polite

As the noble Dieterich and his men

Betook themselves to the palace then.

They wore their swords into the hall.

Among them was no place at all

1100 For the reproving courtier,

Nor might he approach them anywhere,

Because they fared with such array

That never did the light of day

Shine on Dieterich's like, I swear.

1105 The giant who lay fettered there

Had clad himself in raiment fine.

How the ruddy gold from him did shine!

He wore a corselet made of gold;

It signified their wealth untold. 
1110 A helm of steel he also had

Which well became the honest lad.

Its border had with industry

Been ornamented skilfully

With many a jewel set in gold.

1115 Upon his legs the hero bold

Wore greaves of mail that were so fair

That they caught the eyes of the striplings there.

$\mathrm{He}$ also wore a surcoat fine.

Then said the men of Constantine :

1120 "Today we see the best dressed band

That ever journeyed to this land.

How wealthy must these warriors be,

While we live here so wretchedly!

That's because we serve a stingy lord

1125 Who thinks he never can afford

To make us any kind of pleasure -

So enamored is he of his treasure!"

The draperies were hung anon.

Constantine came thereupon

1130 Into a splendid dining-hall.

Ah, what a press arose withal

When the noble Dieterich's following

Assembled there about the king!

They numbered many a goodly youth.

1135 A thousand doughty lads, in truth,

Had come with the exiled lord to dine

There in the palace of Constantine.

Then all the stewards hurried there

Who had the household in their care,

1140 And led Sir Dieterich to his seat

In a manner that was very meet.

Those in charge of the meat and wine

Had to remember all the time

To show great respect for Dieterich's men.

1145 They were very much afraid of them!

Then one led a fierce lion before the king.

It had to be first in everything.

From the lads it took their bread away

And set the whole table in great dismay.

1150 With one hand Asprian grasped it

And against the wall he smashed it,

So that it was shattered all to bits.

How grieved was Constantine by this!

Yet he did not dare to blink an eye. 
1155 Then said two dukes who were standing nigh:

"God alone is our resort

Against these gentlemen here at court!"

One of them departed then

And spoke thus to the serving-men:

1160 "A devilish fellow is in the hall!

He hurled the lion against the wall

Because it wanted to take his bread.

Carefully you had better tread!

If you will follow what I say,

1165 You'll keep out of that fellow's way

And allow him quietly to do

Whatever he has a liking to.

Unless you want to be done in,

Don't ever take his bread from him -

1170 Else with his hand he'll grasp you

And against the wall he'll smash you!"

The queen had noticed without distress

The anger over the lion's death.

She laughed aloud at Constantine.

1175 "Now see", said she, "how that courtier fine

Standing before the table there

Has given your pet the best of care.

This is something I shan't forget!

Verily, you must now regret

1180 That you kept our daughter from the man

Who drove these fellows from his land.

If my advice you now would heed,

Then you would have the envoys freed

And sent back to their homes again;

1185 And you would give to each of them

Raiment of such quality

As one might offer honorably.

What better use for it could you find?

Consider, Constantine, in your mind!

1190 If these men couldn't put up a fight,

How could you oppose King Rother's might?

If he should inquire about his men,

Your land will suffer grievously then.

Now why don't you give the men to me

1195 Who are languishing here so miserably,

That I may bring them into the air.

How very wretchedly they fare!"

Then he said that this he would never do,

Even though one tried to force him to. 
1200 It was no use for her to ask:

They still would have to feel his wrath,

Whether or not it gave her pain.

On the soil of Greece they must remain

As long as he still had his life.

1205 Then said again the queen his wife:

"What miracles would you perform on them?

After all, they're only men!

They come from Adam like everyone.

To God let honor now be done

1210 And let the wretched men go free.

Give them back their liberty!

Of health they have been cheated;

Cruelly they've been treated.

Alas for their fair manhood!

1215 If only I poor woman could

Obtain the help of such a man

To work against the Emperor's plan

As that brave fellow fettered there,

Back to their homeland they would fare.

1220 No matter how much you counsel me,

Ere it should cause you any pain,

How willingly would he refrain."

Berchter said to his master then:

"In the queen we seem to have found a friend.

1225 It may not have injured us at all

That the lion was smashed against the wall:

It seems to have made her very glad.

But none of the others would be sad

If we were to go so far away

1230 That they need see us from this day

Here in their country nevermore.

So many men walk through the door

Muttering beneath their breaths

That I doubt whether we are welcome guests.

1235 They're none of them sure they'll survive this day.

Put their minds at rest, I pray!

Free them of their great concern

And to our lodging let's return,

So that those exiled to this ground,

1240 Of whom so many are walking around

L. 1220 Some lines seem to have been omitted here. 
Suffering most grievously

(How poverty-stricken they must be!),

Can share in your inheritance.

May God of His benevolence

1245 Allow them to forget their pain.

Surely in their own domain

They all were lords of high esteem.

Here the life they live is mean.

The pity I feel for them is great.

1250 Help them for your honor's sake!

You are richer than Constantine.

Why at his table should you dine?

It doesn't become us at all, you know."

Then Dieterich made answer so:

1255 "You are, I swear, a vassal true -

For which may God be good to you!

If from your counsel I turn away,

No other man will I obey."

As soon as they began to dine,

1260 Dieterich went to Constantine

And said: "Twould please me well, $O$ sire,

If to my lodging I might retire

So that with my followers I might be.

They weren't all able to come with me.

1265 Whenever to the court I fare,

Many a man must tarry there

Where we all have our lodging-place.

My lady, show us now your grace,

Because I lead a wretched band:

1270 My best men I no longer command.

Those who paid honor to my name

Have by King Rother all been slain.

There in his realm I might not bide."

To him King Constantine replied:

1275 "Reluctantly we grant your plea.

Repair now to your hostelry.

If aught of mine finds favor with you,

It shall be yours without ado.

I wish to take you into my pay

1280 And honor you in every way

So that the more willing your man may be

To behave at table courteously,

Because he terrifies my wife

Who is as dear to me as my life.

1285 My men aren't bothered by it at all; 
They've often recovered from such a brawl.

But here in this hall it's rarely been tried."

The giant Asprian then replied:

"In truth, sire, I was sore bestead.

1290 Your bear-cub took away my bread."

The noble Dieterich went apace

To where they had their lodging-place,

And acted for a fortnight

As if he were an errant knight,

1295 Until Almighty God began

To send to him many an exiled man.

To them the gates were never closed;

They went out and in just as they chose.

Dieterich cared for their needs himself

1300 And gladly shared with them his wealth.

Berchter and Asprian did the same,

And so did the others in Dieterich's train:

They greeted them in courteous fashion

And on their misery took compassion.

1305 For them the table was often spread.

Whoever wanted to be fed

Was sure of getting a meal there.

And so to the hero they did repair.

One treated them with the utmost tact

1310 And gave them whatsoever they lacked Of which the poor men stood in need,

For till then no one had paid them heed.

From all parts of the city then

Dieterich got a host of men

1315 Who had put up with great distress

In order to prove their fearlessness.

Because they had neither horses nor gear,

At Constantine's court they might not appear.

And so those men of high degree

$1320 \mathrm{Had}$ to live most wretchedly.

Soon the exiles understood

That they were well liked by the hero good

Who now belonged to Constantine's court.

And so to Dieterich did report

1325 A mighty host of fighting-men.

How generously he gave to them!

He treated them like his own kin.

He seated them right next to him.

He gave his butlers all a sign

1330 To keep their goblets filled with wine; 
And all his stewards he directed

That they should in no wise be neglected.

And so in front of every guest

Nourishment of the very best

1335 Which could be gotten anywhere

Was placed on the table for their fare.

As soon as the gentlemen had dined

And had put some of their cares behind,

Then all who were of knightly estate

1340 Were bidden to go from the others straight.

One gave them horses of noble breed

And silken cloaks that were fair indeed,

And along with the horses coats of mail,

So that no sword might make them quail.

1345 Then Asprian came hurrying there

With many a mantle passing fair

From the noble Dieterich's chamber

And arrayed alike each stranger.

He gave a sword to every man

1350 And put a pennon in his hand.

Then on their steeds they began to joust

And rejoiced aloud at every thrust.

Because of this Sir Dieterich's praise

Was heard at the court for many days.

1355 Then there came a troop of warriors fair

Who had been delayed in getting there.

Because it was so late in the day,

They feared that they'd be turned away.

Berchter walked about the men,

1360 Seeking to discern on them

What sort of figure each one had.

He saw there many a naked lad

Seated before him deeply shamed.

To Dieterich Berchter then exclaimed:

1365 "Cast your eyes on these wretched men!

May God be merciful unto them!

How sorely are they mortified

Because their shame they cannot hide!

To all of them you should donate

1370 Clothes befitting their estate.

They are so narrow in the waist,

Their bearing is so full of grace

That they can have no other thought

But to behave as good knights ought.

1375 Truly, the glances of their eyes 
They cast in such decorous wise

That men like these could never be

Other than of high degree.

I allow you to strike off my head

1380 If some of them aren't nobly bred!"

"Your counsel," said Dieterich, "pleases me.

Whoever seeks my charity

Shall find it if it please the Lord."

Then of his goods a mighty hoard

1385 Was set before the strangers there.

In the name of Christ each took his share.

Now it wasn't very long, we're told,

Ere Dieterich, the hero bold,

Had gained for himself six thousand men,

1390 Who were very glad to promise then

That they would serve him every day.

They suited a lord in every way.

To Constantinople there came a man

Whom war had driven from his land.

1395 Arnold was the good count's name,

And he had three barons in his train.

They found themselves in the direst straits

Because they had given up great estates

When they had fled their native ground.

1400 There in the town they walked around

Naked and lamenting sore,

Since no one would open to them his door.

A merchant then drew near their side

(No better was there far and wide)

1405 And said: "My lords, it's plain to see

That you aren't used to poverty.

If you will now agree to do

Exactly as I counsel you,

To Dieterich you will repair.

1410 He will take care of you, I swear,

So that you'll forget your wretched state.

And if aught from me you deign to take,

Then I will equip you with such gear

That henceforth you won't need to fear

1415 Lest anybody see your shame."

"May God reward you for the same,"

The worthy Arnold said thereto;

"And this I solemnly swear to you,

That if the lord be good to me,

1420 I shall repay your charity." 
The exiled count did not delay: At once he set out on his way To Dieterich's lodging with his kin. Politely Dieterich greeted him

1425 And showed him every courtesy. Then he inquired who he might be. Mournfully the count replied: "My enemies have in their pride Banished me from my own land.

1430 Before you stands a needy man. And yet however poor I be, My lineage does make me free. I have betaken myself to you In search of your mercy, hero true."

1435 Said Dieterich: "Be of good cheer!" From Berchter then he wished to hear What presents they could give the lord Which with his honor might accord. The ancient man replied thereto:

1440 "God has been generous to you: $\mathrm{He}$ bestowed on you great wealth indeed. Now help this gentleman in his need. And if you hold my counsel dear, Then let the treasure be carried here.

1445 Stinginess was never our sin. Give a thousand pounds to him And add a little more to it. And I shall also do my bit To help him get the best estate

1450 That in this town we can locate." "Upon my word," said Asprian, "I also want to help the man. I promise to provide the gear For thirty warriors every year."

1455 Dieterich liked the advice he had got. He had the famous treasure brought And gave the noble count a share. Joyfully did the latter fare To Constantine without more ado

1460 And said to him and his retinue: "Dieterich gave this to me.

God grant that prosperous he may be!" To this remarked the gentle queen: " $\mathrm{He}$ is of noble birth, I ween.

1465 Now judge how clever is Constantine. 
What suffering must now be mine, Seeing my daughter might not wed The man from whom this hero fled. If the latter behaves so worthily,

1470 How noble then must Rother be! He surely is a mighty king."

Then said the Emperor's following:

"Lady, how true is what you've said!

Now may the Devil strike them dead

1475 Who were in any way to blame

That here in this land we did remain

And never joined up with Rother's men.

He would have sent us home again

Rich in honors of every kind.

1480 Now each of us has set his mind -

Since that, alas, can never be -

On swearing to Dieterich fealty.

With us he'll share his treasure

And enrich us beyond measure."

1485 The exiled count then did not stay:

He repaired to Dieterich straight away

Together with his kinsmen three.

He greeted them decorously

And sent them on into the town.

1490 A palace for them Berchter found, And Asprian provided there

Thirty warriors passing fair

And furnishings of every sort.

Then all the nobles at the court

1495 Made up their minds up that, come what may,

Nothing was going to stand in their way

Of swearing to be Sir Dieterich's men.

To him the barons hastened then

Along with the counts of high degree

1500 And all the rest of the company

Who served at the court of Constantine.

Only the great dukes stayed behind.

(Of that our story speaks them free -

And they didn't do it, verily!)

1505 But the other brave lads went apace

To the noble Dieterich's lodging-place:

They proceeded there with great array.

He bestowed upon them every day

Not only plenty of ruddy gold

1510 And uncut bolts of silk, we're told, 
But also mantles white as snow -

For which they were not loath to go.

One saw the giant Asprian then

Run to the storeroom and back again

1515 Many a time until each wish

Had been fulfilled by Dieterich.

Then all the nobles with one accord

Began to praise the noble lord.

There wasn't a single man, I swear,

1520 Who had accepted his bounty there

But wished to remain in his command

At the risk of banishment from the land.

As soon as the knights had returned to court

With handsome gifts of every sort,

1525 Then many a demoiselle began

Whispering behind her hand

In the princess' chamber

About the noble stranger

At all hours of the day and night -

1530 How splendidly behaved the knight!

Then said the princess: "Advise me how

I can persuade my father now

To let us see the noble lord

So that with decorum it may accord."

1535 Said Herlint: "I don't rightly know.

You are his only child, and so

You are to him extremely dear.

Get him to give a party here

To which shall come the hero true.

1540 Upon my word I swear to you

That there's no better way to see the man.

We shall never hit on a better plan!"

Thereupon the damsel went

To Constantine's apartment

1545 And said: "If you, my father dear, This Easter should be staying here, It would seem to me a fitting thing To invite to the court your following,

So that the heroes may proclaim

1550 How richly you deserve your fame.

I don't know what good a prince may be

If at his court occasionally

There isn't rejoicing on every side."

To this the Emperor replied:

1555 "Blessings on you, daughter mine! 
How towards honor you incline!

As always your counsel is the best.

Now I shall ask so many a guest

That one will always want to hear

1560 About the revelry and the cheer

At Constantine's festitivity.

So great is the power invested in me

That if somebody stays away,

With his life he will be made to pay."

1565 Back to her chamber the maiden went.

Then Constantine the Mighty sent

Messengers throughout the land

And ordered many a nobleman

To come there to his celebration.

1570 They all accepted his invitation.

Safe-conduct they were guaranteed,

So they had no choice but to proceed.

If anyone was reluctant to,

One threatened to hang him without ado.

1575 And so they preferred to make the trip

Rather than hang on account of it:

They had no choice but to consent.

Straightway every noble went

And sought the company of his peer.

1580 Carefully they prepared their gear.

Not a mantle could one behold

Which wasn't trimmed with cloth of gold.

And such things were so plentiful there

That at them no one thought to stare.

1585 The mightiest princes of the land

Came together in a band

And journeyed to the Hippodrome.

Then sixteen dukes set out from home

With thirty counts coming close behind.

1590 In the city then they all reclined

And shared the wealth of Constantine.

(This custom still holds in our own time.)

When they came to Constantinople Town,

The citadel of great renown,

1595 The princes lodged there overnight

In a style that suited them just right.

As soon as the day began to break,

Each steward went to the hall to take

On behalf of his lord that place therein

1600 Which the court had seen fit to assign to him. 
Then Asprian set out forthwith

To occupy for Dieterich

The place of honor, so we're told.

Eagerly then the giant bold

1605 Set up a very splendid chair

Which had, in truth, been carried there

Heretofore from Ireland.

As far as I can understand,

Of ivory it had been made,

1610 And with rare stones it was inlaid.

However dark the night might be,

The jewels shone forth radiantly.

Then Asprian prepared a board

In such a way that his mighty lord

1615 Might there with honor take his seat.

Now a proud lord was in the Emperor's suite,

A duke named Friederich, I declare,

Whose steward was late in getting there.

To Asprian the latter cried

1620 That he should move his chairs aside;

And he told the giant in addition

How lofty was his lord's position:

He claimed for him as noble a line

As that of the Emperor Constantine.

1625 Said he: "Make room, you ugly ape!

The place of honor is ours to take."

"Upon my word," sir Asprian said,

"You'd better put that out of your head.

The court assigned this place to me.

1630 You've no right here, that's plain to see.

If you are thinking of acting tough,

You'll soon wish you were smart enough

To have put it off for another day

When it would not cause such dismay -

1635 That would seem to me a better plan!

Now go pick on some other man

And leave my chairs right where they stand."

The haughty steward of the duke

Was greatly irked by this rebuke.

1640 He had with him a hundred men

On whom he believed he could depend.

And so he thought that Asprian,

By disobeying his command,

Had shown how foolish one could get.

1645 One of his benches he upset. 
Asprian, the hero true,

Raised his hand without more ado

And gave the fellow a slap so smart

That at once his skull was split apart.

1650 Then for their shields his followers ran:

They wanted to do in Asprian.

Duke Friederich did not delay:

He donned his armor straight away

And called on his friends to help him out.

1655 Then there arose a mighty shout

That the noble Dieterich's seneschal

Was being attacked within the hall

By a mighty company of thanes.

The giant who was bound by chains

1660 Began to roar just like a bear

And broke the chains he was forced to wear.

He took a steel club in his hand

(Four-and-twenty ells it spanned).

Whoever happened to cross his path

1665 Had little chance to survive his wrath.

Then a giant named Grimme began to call:

"Things look pretty bad inside the hall!

I notice Widolt on the move.

Now, Sir Asprian, you can prove

1670 Whether you're truly a worthy man."

Cleverly then Sir Asprian

Began to ask the giant grim

What injury had been done to him

To make him behave so savagely.

1675 "My lord, it had been told to me,"

The valiant Widolt then replied,

"That you were beset on every side.

Since I didn't know who was to blame,

I wanted to see the whole lot slain.

1680 If anyone has made you wroth,

He must surrender his life, in troth!"

"Verily," said Asprian then,

"Nothing have I had from them

But what is honorable and good.

1685 Give over now this angry mood!

Yield your club to yonder man."

Then a giant took it from his hand.

The haughty duke was filled with pain

When he learned that his steward had been slain.

1690 Then all the members of his band 
Hurried there with sword in hand And wanted to do Sir Asprian in.

Then Widolt wanted to hear from him

Who were those fellows drawing near.

1695 "Ah, if only my club were here!

To harm you, master, is their wish.

Today they'll dearly pay for this!

If I don't happen first to die,

Reason enough they'll have to cry.

1700 Now watch how I make them all retreat!"

With his fist he knocked one off his feet

And got the good duke in his grasp,

And tore away his steel casque.

Then by his hair he lifted him high,

1705 And into the crowd he let him fly.

Wherever he seized the other men,

It began to sprout like chickweed then.

Many a lad got such a thump

That he came back to earth with a mighty bump.

1710 Now I don't know how a gleeman came

Running to the court amain

And told the king that a terrible brawl

Had broken out within the hall.

Constantine inquired of him

1715 What the reason was for all the din.

"By the holy Christ," he made reply,

"I'll tell you how the ground does lie.

Some fellow there kept dishing out grub

With what must be the longest club

1720 That ever was seen in any land,

Until they forced it from his hand.

To all of them he shows respect:

Not a single one does he neglect.

Whomever he grabs hold of there

1725 He yanks most awfully by the hair.

How lucky was I to escape so soon!

Over four fellows he let me zoom

So that I sailed right through the air

And never touched earth anywhere.

1730 I was only blocking his light, you see.

He didn't have any use for me."

Widolt was restrained once more,

Bound to the chain as heretofore.

As soon as he was led away,

1735 Then everyone without delay 
Ran to the Emperor with his tale.

Bitterly they all did wail

Because Sir Dieterich's seneschal

Had roughed them up within the hall.

1740 Said Constantine: "I am aghast!

Now tell his master what has passed.

I'd like him to make it up to you.

But with this affair I'll have nothing to do."

As soon as Dieterich heard the news,

1745 Then not a minute did he lose.

He sent his men to his lodging-place

To bring the giant to court apace.

"If he has harmed you in any way,

With his life he shall be made to pay

1750 Here in the presence of all of you."

"This matter we'd rather not pursue,"

The proud Duke Friederich made reply,

"Than that the devil to court should hie

Where we would have to see his face

1755 If he were to show up in this place."

Then they took each other by the hand

And before the king they went to stand.

They said: "O Dieterich, we implore you!

Don't summon that fellow here before you!

1760 He hasn't caused us so much pain

That any of us would ever complain.

Inasmuch as you've fled here from your foes,

You should be honored, Jesus knows!

By everyone in this domain,

1765 Else all of us must suffer shame."

Then Dieterich thanked the gentlemen.

Sore afraid were some of them

That many a blow on them would fall

To make them forget about the brawl

1770 If the giant showed up a second time

There at the court of Constantine.

And so they never did complain.

They all concealed their disgrace and shame.

The men who had been tousled there

1775 Kept silent about the whole affair,

Even though it pleased them not.

Constantine sat deep in thought

And complained about it to the queen.

"Alas, how shamed I now have been

1780 That such a thing was ever done 
To guests who to my court did come From many a land at my invitation. They've suffered such humiliation Pulled by the hair and knocked about -

1785 That their lamenting may never die out. It was Dieterich's man who began it, too, Just on account of a chair or two! His onslaught no one could resist. He knocked them all down with his fist

1790 So that in the mud they came to lie. For the archers they should have raised a cry. Then he might easily have been hit So that he'd have had no joy of it For which I'd always have been glad!"

1795 "Be silent now," the good queen bade, "And let us not pursue this matter.

You know it's only idle chatter.

If he had stood so near to you

That you could have seen all you wanted to,

1800 No good at all would a bow have been:

You would have run away from him

Ahead of the others, I declare!

But if you had given our daughter fair

To the mighty king beyond the main,

1805 No one would dare to cause you shame.

From his domain he would have sent

Warriors so excellent

That no one could invade your land Even with a mighty band.

1810 Reason enough have I to complain!

Suffer now the disgrace and shame

Here in your realm as best you can

At the hands of the noble Dieterich's man."

The Emperor let the matter drop

1815 And sent for his daughter on the spot.

He bade the maiden take her way

To the dining-hall without delay.

Most willingly did she consent:

To visit the court was her intent.

1820 And so without any hesitating

She set out with her maids-in-waiting -

A hundred damsels passing fair,

All with flaxen-colored hair.

Many a bracelet could one behold,

1825 Fashioned out of the ruddy gold. 
Now our story will digress

To tell you something about their dress.

The maiden who led all the rest

Had made herself the prettiest.

1830 She wore a crown of gold so fine

(It was at the bidding of Constantine).

The other maidens one and all

Wore splendid raiment to the hall

In token of their high esteem.

1835 Silken stuffs of splendid sheen

Had been embroidered, so we're told,

Through and through with thread of gold

And lined with sable and with vair.

Many a gentleman had to stare

1840 When he beheld the damsel fair

Leading her maids-in-waiting there.

Then a band of noblemen made their way

Into the hall without delay.

Dieterich was in the van;

1845 He led there many a doughty man.

So marvelous was their array

That never before or since that day

Was raiment seen that could compare

With what the heroes were wearing there.

1850 Their shirts were woven of silk, we're told;

Their caps were made of cloth of gold

And adorned with many a precious stone.

From Dieterich a ruby shone.

It was a jewel so passing fine

1855 That many another it did outshine

Which would have got the highest praise

If it had not drawn everyone's gaze.

How in the world could mantles be

Fashioned more becomingly

1860 To enhance a hero's bearing

Than what those knights were wearing?

Lined with ermine was every fold

And covered over with cloth of gold.

If anyone was standing near,

1865 Green as grass it did appear.

As soon as the color no longer shone,

The fairest jewel to look upon

Gleamed in all its nobility.

What thing more precious could there be?

1870 Besides all this, it smelled sweet. 
A people called the Flatfeet

Had honored Asprian therewith.

Later he gave it to Dieterich.

That was the reason why Dieterich's cloak

1875 Was so admired by all the folk

Who had assembled on the spot.

Because they stood around and gawked,

The damsel was cheated of her delight:

She never got to see the knight.

1880 The festival continued on

Until three days had come and gone.

On the morning of the final day

The wandering minstrels made their way

To where Sir Dieterich's table stood.

1885 Christ knows, he gave as a gentleman should!

The worthy lord could not say no.

His handsome cloak he did bestow

Upon a minstrel worn with care

Who was lucky enough to have hurried there.

1890 The others followed his example:

Not a knight retained his mantle

Of those whom Dieterich had brought.

In very truth, it mattered not

To whom they gave their cloaks away.

1895 Not one did they keep for themselves that day!

The festival had reached an end.

All the guests began to wend

Back to their homelands once again,

With the exception of Dieterich's men.

1900 To their abode they all withdrew

And dressed themselves in garments new.

He proved himself so excellent there

That never before or since, I swear,

Lived there a hero anywhere

1905 Who was the noble Dieterich's peer.

And so we gladly praise him here

Because of the excellence he did show.

With everyone it wasn't so.

The festival had come and gone.

1910 Then everyone repaired anon

To the chamber of the youthful queen

L. 1901. A line is missing here. 
To tell about the clothes they'd seen.

Truly, they were much impressed

With the way that Dieterich had been dressed.

1915 As soon as one went through the door,

Another stationed himself before

Until the maiden had heard so much

That in her heart she felt the touch

Of tender passion for the man

1920 Who had journeyed thither to her land.

At that time she still was a stranger to him.

With the hero later she was to win

Her share of this world's gladness,

Together with some sadness.

1925 Within the chamber quiet reigned.

The lovely princess then complained:

"Ah, Dame Herlint, now you see

How my thoughts must always be

With the noble Dieterich.

1930 It is, in truth, my fondest wish

That I might see him secretly -

If that could be done with propriety

On the part of the very worthy knight.

With five of my bracelets I would requite

1935 The one who should not hesitate

To take a message from me straight

And swiftly bring the stranger

Hither to my chamber."

Said Herlint: "I'm the one to send!

1940 Upon your errand I shall wend,

Whether or not it bring us shame:

To the hero's lodging I'll go amain.

For virtue he's so famous

That he will never shame us."

1945 The lady Herlint did not stay:

She went to a chamber straight away

And chose for herself a splendid dress

Such as ladies oft possess.

As soon as she had put it on,

1950 The clever maid set out anon

To the noble Dieterich's residence.

He welcomed her there with deference.

Beside him then she took a seat

And into his ear began to speak:

1955

"My mistress bids me say to you

That she offers her devotion true: 
Her love for you she does avow.

Go to her apartment now.

Waiting there the maid will be

1960 To greet you with such courtesy

As with your honor may well accord.

You can be sure of this, my lord,

That in my mistress you will find

Devotion of the truest kind."

1965 Now hear the answer that Dieterich gave!

"You're guilty, ma'am, of a sin most grave

By treating thus a stranger.

To many a lady's chamber

I've gone before when that might be.

1970 Now why do you make fun of me?

The poor have always been treated so.

Those aren't your lady's words, I trow!

So many dukes and princes, too,

Are in the Emperor's retinue

1975 That you might just as well have had

Your little joke with another lad -

Less blame would you have earned thereby!

In Hell you now deserve to fry

For wanting to make a fool of me.

1980 Howsoever poor I be,

I once was held in high esteem

As a mighty count in my demesne!"

Then said Dame Herlint to the knight

(She knew how to choose her words aright):

1985 "O no, Sir Dieterich, I implore you -

Don't think that's why I've come before you!

God knows, whatever I said is true!

My mistress bade me come to you.

In very truth, she is amazed

1990 That you've been at the court these many days

And have not asked in all this time

To see the daughter of Constantine.

Seldom has a splendid knight

Committed such an oversight.

1995 Now don't reprove me for my speech.

Whatever heights you yet may reach,

'Twill please the princess well, I vow,

Though you do not care to see her now.

But if you were to visit her,

2000 "Twould not turn out amiss, dear sir."

Now listen to the lord's reply 
(He knew that the lady did not lie):

"There are so many informers here

That the man who holds his honor dear

2005 Must conduct himself with the greatest care.

The homeless man is well aware

That he can never behave so well

That all who at the court do dwell

Will look upon him favorably.

2010 Now tell your mistress this for me:

My service I do offer her;

But any visit I must defer

Lest it should be misunderstood.

I sorely fear that we both could

2015 Be slandered very grievously.

Then Constantine would banish me

Forevermore from his domain.

Then I should have to flee, good dame,

From Rother as long as I drew breath

2020 And nowhere should be safe from Death."

Herlint wished to be on her way.

The noble Dieterich bade her stay

And summoned his goldsmiths there to him.

He bade them speedily begin

2025 To cast a pair of silver shoes

(Not a minute did they lose)

And a pair of golden shoes as well,

Such as might suit a demoiselle;

And he bade Sir Asprian see to it

2030 That on one foot alone should fit

The pair of shoes which he then should take

And give to the lady Herlint straight

Along with a mantle fair to behold

And a dozen rings of ruddy gold.

2035 (That is the proper way, I ween,

To thank the confidante of a queen!)

Then over the yard she skipped with pleasure

Back to her mistress with her treasure.

Herlint did not hesitate:

2040 To the princess' chamber she hurried straight

And told her how, in very truth,

Dieterich, the noble youth,

Was much concerned for his good name.

"This is what I learned, good dame:

2045 He holds the Emperor's favor dear.

He says that he may not see you here, 
Else his good name he'd surely lose.

Now cast your eyes on these lovely shoes!

They were given to me by the worthy knight

2050 With other things of much delight.

Upon my word, this mantle fair

(Lucky me that I went there!)

And these twelve armlets fair to see

The excellent man bestowed on me.

2055 Never could there be, I swear,

A knight more winsome anywhere

Upon this earth than Dieterich.

May God not strike me dead for it,

But I stared at him against my will -

2060 On account of which I am blushing still."

The princess answered: "Now I see

That happiness is not for me,

Since to visit me he doesn't choose.

If you will give me now these shoes,

2065 You can have all the gold that goes therein:

That's because of my regard for him."

At once the exchange was agreed upon.

The golden shoe she first drew on,

And then the silver one she took.

2070 It would only go on the selfsame foot!

"Oh goodness me!" the maid exclaimed.

"How both of us have now been shamed!

Whoever selected these shoes so fair

Has made an error, I declare.

2075 I never shall get this one on!

In truth, you must again be gone

And ask Sir Dieterich for me

(Display the utmost courtesy!)

To let you have the other shoe

2080 And visit me here without more ado,

Provided he should really be

A man of true gentility."

"Oh dear!" Dame Herlint then replied,

"How sorely are we mortified

2085 Because of this, my mistress dear!

Now this I can tell you without fear,

That though the shame be always mine,

I'm ready to go there another time."

The lovely maiden thereupon

2090 Lifted the dress which she had on

All the way up to her knee. 
Not a thought did she give to propriety!

She quite forgot a lady's gait.

Across the yard she hurried straight

2095 To the noble Dieterich's residence.

$\mathrm{He}$ greeted her with deference

And put on a demeanor

As if he had never seen her.

And yet he was at once aware

2100 Why she again had hurried there.

To Dieterich said the damsel then:

"It is my duty once again

To bring a message to you here.

A mistake was made with the shoes, I fear.

2105 I gave them to my dame, that's true,

But only out of regard for you.

Now we would like the proper one.

My lady bade that I should come

And ask that you give to her the mate

2110 And request that you come and see her straight,

In case you really claim to be

A man of true gentility."

Said he: "I'd go there willingly,

But the chamberlains would peach on me."

2115 Said Herlint: "They are not at home;

They're watching the games at the Hippodrome.

The knights are hurling the javelin;

In games of war they seek to win.

Now I will go ahead of you.

2120 Of your retainers take but two

And follow after me, I pray,

To my lady's chamber without delay.

No one will see you passing by

On account of all the hue and cry.

2125 I shall see to it, hero fair,

That the princess alone will be waiting there."

Herlint wished to be on her way.

The clever fellow then did say:

"Wait till I question my chamberlain.

2130 I'll find out about the shoes from him."

Swiftly Asprian showed his head.

"Ah, what did I do to you?" he said.

"All these tasks I can't complete!

You've kept me the whole day on my feet

2135 With always some new job to do,

More than you ever did hitherto! 
A great many shoes were cast today Which the lads have carried all away. If any of them we still can get,

2140 You soon shall have them to inspect." Thereupon the giant took The lovely shoes for the other foot And a mantle very fair to behold And a dozen rings of ruddy gold,

2145 And gave it all to the lady fair. Stealthily she went from there In a most contented frame of mind And left Sir Dieterich behind.

To her mistress then she hastened to tell

2150 A piece of news which pleased her well. Impatiently the damsels waited.

Dieterich deliberated

How he might see the maiden fair Without any scandal whatsoe'er.

2155 "That's easily done," said Berchter then. "At the Hippodrome I'll have my men Raise up such a hue and cry That everyone will hurry by And no one will pay you any heed."

2160 Then he ordered the giants to proceed, And saddled himself his courser fair. Quickly they set out from there. The old boy galloped at their head; A thousand men-at-arms he led.

2165 Widolt with the club, we're told, Hurried then along the road, Jumping up and down like mad Just as if he were a stag. Asprian came tumbling along

2170 (He was the minstrel of the throng). Twelve full fathoms Grimme sprang, And so did the others of his band. Then he seized a rock of monstrous size. The result was that none of the spies

2175 Noticed Dieterich for the shouting When the giants set out on their outing. Before the window stood the dame. Hurrying over the courtyard came Dieterich, the youthful knight.

2180 The greeting he got was most polite. Accompanied by heroes twain, 
Dieterich to the maiden came.

Quickly the door was opened wide.

The handsome fellow stepped inside.

2185 To meet him went the youthful queen

And welcomed him with courteous mien.

She said that whatever his wish might be

She would fulfill it willingly,

If with their honor it might accord.

2190 "I wished to speak with you, my lord,

Because you are said to have no peer:

That is the reason I asked you here.

Concerning this pair of shoes so neat -

Help me to draw them on my feet!"

2195 "With pleasure", Dieterich replied.

"To you can nothing be denied."

The hero knelt then at her feet

In a manner that was very meet.

She put her foot upon his lap.

2200 No lady was better shod than that!

The clever fellow then did say:

"Madam, hear my words, I pray!

Tell me in all honesty,

As a Christian you would be:

2205 Since you've been wooed by so many men,

If you could choose from all of them,

Who is the man from all that host

That pleases you the very most?"

To him the damsel said: "I vow

2210 To answer your question truthfully now.

Sir, by my immortal life,

As I would be a Christian wife,

If in response to some command

The bravest heroes from every land

2215 Were to assemble on common ground,

Never would a man be found

Who might claim to be your equal there.

By all that I hold dear I swear

That never did a woman bear

2220 A child so comely anywhere

That with propriety it might

Sit beside you, worthy knight,

So excellent have you proved to be.

But if the choice were up to me,

2225 I'd take a bold and worthy man

Whose envoys journeyed to this land 
And since have spent a weary time

In the dungeon of Lord Constantine.

Rother is that hero's name,

2230 And he dwells in the West beyond the main.

A maiden I shall always be

Unless the fair hero is given to me!"

Now hear what the clever fellow said

As soon as he heard whom she would wed.

2235 "If Rother is the lucky man,

I'll bring him here as fast as I can.

There doesn't live a man today

Who treated me in a better way -

For which he will always have my thanks -

2240 Until he was ridden by arrogance.

He helped me often in time of need -

For which may God give him his meed!

We dwelled together in the land

And happily lived as lord and man.

2245 He always was gracious and good to me,

Though now in exile I must be."

The princess said: "From what I hear,

It wasn't Rother (that is clear!)

Who drove you hither, hero true,

2250 Seeing he's so revered by you.

From whencesoever you do fare,

You've come as an envoy to us, I swear!

The king's good will you cherish so!

Now tell me all I want to know.

2255 Whatever today is said to me

I shall keep secret faithfully

Even to the Judgment Day."

Thereupon the lord did say:

"To God I now commend my life

2260 And to you also, gentle wife.

Your feet are lying, I avow,

In the lap of Rother now!"

How very great was her dismay!

At once she pulled her feet away

2265 And said to him with eyes downcast

(Truly, she was much abashed!):

"By my pride l've been misled.

Never was I so ill-bred.

It was of me most indiscreet

2270 To put upon your lap my feet.

But if Rother really is your name, 
Then you can never, O King, attain

To greater merit than you have now. Of many wonderful things, I vow,

2275 You have achieved the mastery, Whatever may be your pedigree.

My heart had a presentiment!

And if by God you have been sent,

Then that will give me much delight.

2280 But I cannot believe it quite

Until you prove that it is so.

Then though it cause the whole world woe,

I certainly shall have no fear

In running off with you from here.

2285 But without the proof that may not be.

Yet no man lives so splendidly

That I would take him ahead of you

If what you've said is really true."

Thus did Dieterich reply

2290 (Truly, he was very sly):

"I am bereft of every friend

Excepting for those wretched men

Who are lying here in captivity.

If they were to get a glimpse of me,

2295 From their behavior you would know

That what I've said is really so."

Then said the princess: "Verily,

I'll get my father to agree

To let those men go free a while:

2300 I'll manage that with a little guile.

But he won't surrender their custody

Except to the man who can guarantee

That missing will be none of them

When it shall be time once again

2305 To bring them into that dungeon bare

Where they so wretchedly do fare."

Said Dieterich: "If it must be,

I'm ready to stand surety.

Tomorrow I intend to dine

2310 Here at the court of Constantine.

You can believe that I speak the truth!"

Thereupon the handsome youth

Got from the lovely maid a kiss.

And so with honor he was dismissed.

2315 Then over the yard he went apace

To where he had his lodging-place. 
As soon as Berchter noticed that,

He quickly called the giants back.

From Rother then the good duke heard

2320 Everything that had occurred.

His heart was filled with great delight.

They both began to praise God's might.

All night the damsel lay awake.

What a heavy turn her thoughts did take!

2325 As soon as dawn came to the land,

She took a staff into her hand

And dressed herself in garments dun

Like one who has become a nun.

Then over her shoulder a palm-leaf she put

2330 As if she would go from the land on foot.

Quickly then the maiden went

To Constantine's apartment.

Upon the little door she knocked.

By her father then it was unlocked.

2335 As soon as she had been let in,

How cleverly she said to him:

"I'm at your service, father dear!

Mother mine, be of good cheer!

Now listen to what this night I dreamt!

2340 Unless Almighty God consent

To send his angel down to me,

In the abyss I needs must be

Even before my life runs out -

Of that there can't be any doubt!

2345 Now no one can make me change my plan

Of dwelling in a foreign land

So that for my sins I may atone

As long as this world is still my home!"

Sadly then said Constantine:

2350 "Do not speak so, daughter mine!

Let me know what you desire.

I'll save you from eternal fire."

"Father, that can never be

Unless the envoys are given to me.

2355 I wish to have them bathed and clad,

So that once more each wretched lad

May feel contented enough to smile -

If only for a little while.

For three days I would care for them.

2360 Then they'll be given back again

To be imprisoned once more by you." 
The mighty Emperor said thereto

That he would do that willingly

If she found someone to agree

2365 To pledge his life that the wretched men

Would be returned to him again

Without a single one having fled.

To this the lovely maiden said:

"So many men today I'll ask

2370 That someone will accept the task

Who lives so honestly that you may

Give them to him without dismay."

Then Constantine replied thereto:

"Daughter, that I'll gladly do."

2375 As soon as it was time to dine, One saw the Emperor Constantine

Make his way into the hall.

Then Dieterich did not wait at all:

Together with his following

2380 He hurried there before the king.

As soon as they had begun to dine,

The lovely maiden came betime

And started to walk around the table,

Weeping as sorely as she was able

2385 And asking who of them would agree

To offer himself as surety

Against the return of the envoys fair.

Not one of them dared to grant her prayer.

Even the great dukes were afraid

2390 To offer the maiden any aid.

At last she drew near to the man

With whom she had worked out her plan.

To him the damsel said anon:

"Sir Dieterich, now think upon

2395 The excellent qualities you possess

And rescue me from my distress!

Go surety for the envoys fair:

The king will give them into your care.

Faint-hearted are my father's men:

2400 Not one will risk his life for them.

But you, dear sir, will honor me

By letting me share your nobility

So that I may have the benefit.

Even though you would refrain from it,

2405 Your excellence wouldn't allow you to.

You shall vouchsafe it, hero true!" 
Dieterich answered: "Willingly,

Since it is you who ask it of me.

It's only my life that will be at stake.

2410 I'll do it, fair damsel, for your sake."

Constantine set the envoys free

Against Sir Dieterich's guarantee:

Into his charge he delivered them.

Together with the Emperor's men

$2415 \mathrm{He}$ hastened thither to the cell

Where they were lying, so we hear tell.

The wretched men lay on the ground:

They were too weak to move around.

It was a sight to make one weep!

2420 The mighty Berchter could not keep

From shedding many a bitter tear

When their lamenting reached his ear.

The dungeon-door was opened wide.

Swiftly the daylight fell inside.

2425 It struck upon the prisoners' eyes.

They started blinking in surprise.

Erwin was the first of the men

To step forth from the dungeon then.

When Berchter caught sight of his son,

2430 With anguish he was overcome.

He quickly turned his face away

And wrung his hands in his dismay.

He did not dare to express his woe.

And yet he may never have suffered so

2435 Since he first saw the light of day.

Erwin was in a pitiful way!

He hardly had the strength to stand.

Truly, he was a wretched man!

The twelve counts soon came into view,

2440 Followed by their vassals true.

Now our story will let you hear

Just how the good lads did appear.

Black and dirty was every knight,

All discolored by their plight.

2445 On Master Lupold, so we're told,

Nothing else could one behold

Except a wretched little breech

Which round his waist could hardly reach.

The unhappy fellow was indeed

2450 A picture of the direst need -

Bruised and swollen everywhere! 
Dieterich, the hero fair,

Stood there overcome with grief;

Yet tears might bring him no relief:

2455 He dared not betray the valiant band.

The ancient Berchter then began

To walk around the captive men,

Carefully observing them.

Nothing had ever grieved him so

2460 As the plight of his handsome sons, I trow!

Sir Dieterich commanded then

That one should lead the noblemen

To his abode without delay;

Lupold and Erwin alone might stay.

2465 One let them walk about in the air

Without anyone to guard the pair.

The noble Erwin then did say:

"Master Lupold, tell me, pray,

If you can make out over there

2470 An ancient man with a beard so fair

Who all the time kept watching me

As if he were troubled wondrously.

From me he turned his face away

And wrung his hands in great dismay.

2475 He didn't dare to express his woe, And yet he may never have suffered so.

What if Almighty God above,

In token of His lasting love,

Intends to give us now a sign

2480 That we shall come from here in time?

Brother dear, it seems to me

That our good father he well may be."

Then both began to laugh aloud.

Happy and sad were the heroes proud.

2485 The wretched men were set at large, Given into Dieterich's charge.

On the morning of the second day

The damsel asked her sire to say

That she might go and see the men:

2490 She wished herself to care for them.

When he had given his consent,

How quickly over the yard she went

To the noble Dieterich's dwelling-place.

Then all the knights of a foreign race

2495 Were asked by him to go outside.

None of the gentlemen might abide 
Who wasn't of the closest kin

And had sailed across the sea for him.

The handsome envoys then were clad

2500 In the finest raiment to be had

And given armor of the best:

This was at Dieterich's behest.

The tables were covered with food anon.

One put Sir Berchter thereupon

2505 In charge of both the food and wine

As long as his sons were pleased to dine.

When all the knights had been seated there

And had forgotten some of their care,

The noble Dieterich stepped apart

2510 And came back with an excellent harp.

Then he sneaked behind the tapestry.

How quickly rang out a melody!

Those who had begun to drink

Had to let their beakers sink,

2515 So that on the table the wine was shed.

Those who were busy cutting the bread

Had no choice but to drop their knives:

They lost their wits from glad surmise.

2520 Everyone could hardly wait

How many put on a cheerful guise!

To hear what turn the music would take.

Loudly then a melody sounded.

Over the table Lupold bounded,

Followed by Count Erwin then.

2525 How warmly did the noblemen

Salute the harpist of high degree

And kiss him most decorously!

The damsel then could clearly see

That the noble Rother he must be.

2530 As soon as the damsel had turned from there,

The envoys were allowed to fare

Everywhere in the famous town

Without anyone to follow them round.

When Constantine's men got wind of this,

2535 They told him that something was amiss.

He answered: "Do not be concerned!

Dieterich pledged that they'd be returned.

L. 2518 Here a line is probably missing in which mention was made of the playing of the second melody. 
His intellect is so very keen

That none will get away, I ween!"

2540 Upon the bidding of the queen

One began to sweep the dungeon clean.

When three full days had come and gone,

The messengers rvere seized anon

And brought into the dungeon-cell,

2545 Where they once more were forced to dwell.

Of bedding then a goodly store

And other nice things by the score

Were smuggled in to them secretly;

And so most comfortable they might be.

2550 Wheaten rolls and white bread, too,

Tasted good to the heroes true.

The damsel then dispatched a man

To Dieterich with a clever plan.

He bade his followers then prepare

2555 A tunnel leading to the air

Whenever they wished to go from there.

And so the prisoners reclined

In a contented frame of mind.

They lay at ease there in the hold

2560 For twenty days, so we are told, And wanted nothing for their board.

To vigor then they were restored.

Beneath the heavens arose meantime

Against the Emperor Constantine

2565 Princes two-and-seventy strong

From the land of Egyptian Babylon.

They rode at the head of the mightiest band

That had ventured forth from any land.

Ymelot, a paynim king,

2570 Was determined to capture him.

Nothing could stand in his way.

He wanted to extend his sway

Over the kingdoms one by one.

Throughout the whole of heathendom

2575 His commands were greatly feared.

Like God he wanted to be revered.

(Similin was the name of his wife.

At Jerusalem later he lost his life.)

L. 2555 A line is probably missing here.

L. 2566 Egyptian Babylon - Cairo. 
In haste a man came riding then

2580 Ahead of the terrible Ymelot's men

To Constantinople Town,

The citadel of great renown,

And let it be known to Constantine

That there was very little time

2585 If the didn't want to be overrun-

To his realm a mighty host had come!

Constantine said thereupon:

"What man ever was so strong

That he would dare invade my land?"

2590 Now hear the reply of the hurrying man:

"Your overweening pride, my lord,

Is something you cannot afford.

That's just what they are doing now!

It is King Ymelot, I vow,

2595 From the land of Egyptian Babylon.

Princes two-and-seventy strong

Are riding here in hostile wise.

I saw the van with my own eyes.

So many tents have they pitched, I swear,

2600 That a hundred thousand may well be there!"

As soon as Constantine heard this news,

His spirits he began to lose.

Then Dieterich, the hero good,

Cheered him up as best he could.

2605 He said: "Despair not, Constantine!

I'll pledge to you this life of mine

If you will give those men to me

Who are lying here in captivity.

If horses and armor they only had,

2610 They'd furnish many a valiant lad.

Now gather your followers straight away:

We must ride forth without delay."

"May God reward you," the king replied.

"My chamberlains have set aside

2615 Both the horses and the gear

With which the envoys traveled here.

They'll get it back again all right,

Seeing that you, most worthy knight,

Have pledged your word to stand by me

2620 Now that I need help so desperately."

Constantine agreed to do

As Dieterich had advised him to.

He sent his messengers far and wide. 
Then many brave men began to ride

2625 To Constantinople Town, The citadel of great renown,

So that before three days had passed

Fifty thousand he had amassed.

Thereupon the heroes bold

2630 Hurried thither to the hold

And let the door be opened wide

And had the twelve counts brought outside

Together with their trusty men.

Quickly one gave back to them

2635 What they had brought across the sea.

The valiant Dieterich speedily

Received them all into his troop

And fitted them out from head to foot.

They mounted steeds that were snowy white.

2640 Then filled with hope was the worthy knight.

The youthful men set out apace.

Upon their steeds they began to race.

Twenty thousand warriors bold

Behind Sir Dieterich's banner rode

2645 In armor shining through the land.

Under Constantine's command

Many a brave lad rode along

To defend the realm from the paynim throng.

For seven nights, our story tells,

2650 They rode to meet the infidels.

The princes two-and-seventy strong

From the land of Egyptian Babylon

Pitched their tents so near to them

That they were able to make out then

2655 The smoke from the camp-fires rising clear.

Then many a man was seized by fear.

Then Dieterich cheered up the lot:

He pitched his tent in the foremost spot,

Right between the armies twain.

2660 His valiant followers did the same.

The day drew swiftly to an end.

Constantine's troops began to commend

To one another their children and wives:

They feared lest they might lose their lives.

2665 Dieterich and his trusty men

Stealthily went walking then

And plotted against the paynim throng

Who were lying there with an army strong. 
They pictured how great would be their fame

2670 If the famous Ymelot should be slain

Or taken prisoner by them

Without losing any of Constantine's men.

Then Widolt said: "I'm willing to swear

That when we come among them there

2675 I shan't be overly circumspect,

Seeing that Christ they do reject.

But this much I can guarantee,

That if my hands shall be set free

Some of them will dearly pay!"

2680 Then Asprian armed himself straightway,

And twelve good knights who knew no fear

Slipped into their battle-gear.

Eager were they for the fray!

Then a corselet shone as bright as day;

2685 It was worn by the hero Asprian.

There never lived so bold a man

But with his life would have to pay

If he were ever to cross his way

Among the paynim host, I swear.

2690 Mightily they rose up there.

Then Berchter issued a command

To all the men in Dieterich's band

To keep a careful lookout

And raise their voices in a shout.

2695 Said he: "My lord and his trusty crew

Have with the king a rendezvous:

Constantine has sent for them."

Many a doughty hero then

In goodly armor could be seen.

2700 No one knew about the scheme

Excepting those of the nearest kin

Who had sailed across the sea for him.

To the horses Dieterich went anon.

Then above a handsome steed there shone

2705 A golden hauberk through the land.

It was worn by the most ferocious man

Who ever drew a breath of air

Since God made Adam, I declare!

A terrible club was in his hand

2710 Before which not a thing could stand.

Then heartened by him was Dieterich's crew.

Widolt it was, a hero true.

The faithful Lupold then began 
To warn the giants to a man:

2715 "Clad in your corselets shining so,

From our midst beware to go

Lest you should throw too great a glare."

Then Dieterich rode with his men from there

And circled around the paynim throng

2720 Who were lying there with an army strong.

He asked whomever he did see

Where the Emperor Ymelot might be:

$\mathrm{He}$ had been detained in getting there

And was bringing many a hero fair.

2725 From one to another he was sent

Until he came to a splendid tent

In which was lying the paynim lord.

Asprian then unsheathed his sword

And bade him not to blink an eye

2730 Unless it was his wish to die.

Ymelot didn't make a sound

When he saw the club being swung around.

It seemed to him a terrible thing!

Captured then was the mighty king.

2735 Dieterich and his trusty men

Proceeded with great valor then.

They fell upon a compact group

And laid low the entire troop.

Widolt refused to give away

2740 His club to anyone that day.

Whatever paynims crossed his path

He struck like thunder in his wrath.

Whenever he came into the press

He hit them with such ruthlessness

2745 That their defence was shattered

Like dust that the wind has scattered.

The twelve fierce giants then began

To take the life of many a man.

The paynim troops were forced to flee

2750 With Death pursuing them pitilessly.

Widolt was restrained once more,

Fettered as he had been before.

Thereupon Sir Dieterich went

Back to the encampment

2755 And showed to everyone a face

As though nothing at all had taken place.

Dieterich bade his noble crew

Return to camp without ado 
And leave their horses undisturbed,

2760 No matter what clamor might be heard.

Then from the sentry at his post

A cry went over all the host:

"Rise up now, Lord Constantine!

There is coming to these ears of mine

2765 A mighty clamor from the foe. They're starting to attack, I trow!"

Ah! how terrible was their fright

As soon as they heard the sound of flight

Coming from the paynim throng,

2770 Who were lying there with an army strong.

To don his armor Constantine ran,

And with him many a valiant man.

Then some of his followers said to him:

"Now look at Dieterich, O King!

2775 He doesn't stir out of craven fear,

Although it was he who led us here.

O Constantine, it's plain to see

That you've been undone by his treachery."

Constantine jumped on his steed

2780 And rode off with the greatest speed

To where a splendid tent was pitched.

"Rise up now, Sir Dieterich!

We're being attacked by the paynim band.

Death draws near for many a man!"

2785 Then in a loud voice Ymelot spoke:

"Sir, there is no need to joke.

Last night, ere the break of day,

As sleeping on my couch I lay,

A terrible man came in to me

2790 And carried me off bodily.

My retinue have all been slain.

They cannot harm you ever again."

As soon as Constantine heard of this,

He turned away from there full of bliss

2795 And told the news to his following.

"Captured is the paynim king!

For this must Dieterich be acclaimed.

Now everyone must be ashamed

Who ever talked to the despite

2800 Of such a very worthy knight

Wrongfully and without cause."

Then many a good lad did not pause

But hastened to where Dieterich stood 
And expressed his thanks as best he could.

2805 Constantine jumped from his horse and went Ahead of his men into the tent.

He stretched his hands out to the knight.

"May God Almighty now requite

Both you and your following

2810 For having captured the paynim king.

Upon my honor, worthy lord,

How glorious will be your reward!

If there is anything of mine

Which you may wish to have some time,

2815 You only have to ask for it."

Of all their worries they were quit.

As soon as day came to the land,

One handed over many a man.

Dieterich did not delay:

2820 He led King Ymelot straight away

Into the presence of Constantine

And handed him over to him betime.

The clever man said thereupon:

"An envoy we must have anon

2825 To ride and let the ladies hear

All that we have accomplished here."

Then Constantine replied thereto:

"In truth, that envoy shall be you!

'Twill please my daughter well, I ween.

2830 And make it known to my wife the queen

And to all the other ladies, too,

How joyfully we follow you

Back to our native land again.

Now give instructions to some of your men

2835 That here with me they must abide."

The clever fellow then replied

That he would very gladly do

Whatever the king desired him to.

Dieterich departed then

2840 Together with his trusty men.

He sent his army to Constantine

And thanked them all full many a time.

No other men did he retain

Save those who had sailed across the main.

2845 Then he revealed to his valiant crew

Just what it was he planned to do.

Then hope arose in the doughty band

Of seeing once more their native land. 
No time at all did Dieterich waste:

2850 With a splendid banner he rode in haste Back to Constantinople Town, The citadel of great renown.

The clever fellow then did say

That with his men he had run away.

2855 At this the queen wept bitterly.

"Alas, where now may Constantine be,

And where may be that valiant band

Which gathered here from many a land?

Tell me, Dieterich, I implore!

2860 Shall we ever see them more?"

"Upon my word, to hope were vain.

By Ymelot they've all been slain.

With an army he is riding here

And means to destroy the town, I fear.

2865 I think he is too strong for me!

Now I shall sail across the sea.

Both the children and the wives

Must prepare to lose their lives

If in the town they do remain -

2870 By Ymelot they will be slain!"

Constantine's wife led with her there

Her daughter (she was a maiden fair),

And both implored the worthy knight

Just as urgently as they might

2875 To save them from the heathen throng

Who were riding there with an army strong.

The crafty fellow ordered then

The palfreys brought at once to them,

And he led the queen and her daughter, too,

2880 Down to the ships without more ado.

Truly, there could then be seen

Ladies of most lovely mien

Weeping aloud and tearing their hair:

They had to give vent to their despair.

2885 Behind Sir Dieterich went along

From out the town a migthy throng.

It was the hope of all those wives

That on the sea they might save their lives.

The clever man did not dissent.

2890 It all was done with sly intent.

The noble Dieterich bade his men

Swiftly board the vessels then.

Asprian, the hero bold, 
Brought the treasure into the hold.

2895 They wished to reach the open sea. Then King Rother did decree

That the mother be left upon the shore

And the daughter be taken and no one more.

Then many a tear the old queen shed.

2900 "Alas, Sir Dieterich," she pled,

"To whom would you, most worthy knight,

Abandon us women in our plight?"

Further did the good queen say:

"Take me into your ship, I pray,

2905 That I may be at my daughter's side."

The clever fellow then replied:

"Madam, you need not complain!

Constantine has not been slain.

We've captured the mighty infidel.

2910 For Constantine it's turned out well.

$\mathrm{He}$ is riding back to his kingdom now,

Bringing pleasant news, I vow.

In three days' time he will be here.

Now you can tell him without fear

2915 That westward does King Rother ride

With his fair daughter by his side.

Now God preserve you, gentle dame!

Dieterich is not my name."

"O happy me," the queen did say,

2920 "That ever I saw the light of day!

Now may Almighty God above,

In token of His lasting love,

Let you keep my daughter dear

Free from sorrow many a year.

2925 Worthy man, I tell you true:

It wouldn't have been so hard for you

To win the maiden for your own

If the choice were up to me alone.

Now though the king will tear his hair

2930 When he hears about his daughter fair,

That isn't going to bother me,

Now that Rother you've proved to be.

$\mathrm{Be}$ on your way now, hero true,

And may Saint Aegidius watch over you!"

2935 Then said the lovely demoiselle:

"Mother mine, God keep you well!"

Thereupon the ladies fair

Laughing merrily went from there 
Back to the palace of Constantine

2940 And wished for Rother many a time

That God might bring him over the main

With honor to his own domain.

As soon as Rother came back home

Sailing west across the foam,

2945 His lovely wife did then become

Pregnant with a blessed son.

By that time Amalger was dead,

From all the realm had order fled.

For that six margraves were to blame

2950 Because they wanted to proclaim

Hadamar as King of Rome.

(In Diessen was the lord at home,

And he was a great duke, verily.)

Those who had pledged their loyalty

2955 To Rother while he was away

Defended the crown for many a day

On behalf of their mighty errant lord

Till Wolfrat was knighted with the sword,

Standing in a splendid ring.

2960 (He was the lord of Tengeling

And was, in truth, King Amalger's son.

Never from one line has come

Such a host of heroes fair.)

The worthy man defended there

2965 Both the people and the throne

Until King Rother came back home.

In strife lay all the countryside.

The valiant Rother might not bide.

He gave his travel-weary men

2970 No chance to rest their bodies then:

He had to bring order to his land.

The faithful Lupold he did command

To guard the ladies while he was gone.

The other good knights thereupon

2975 Mounted their steeds in full array.

Many an honest lad that day

Galloped over the mountainside.

To Verona with their king they hied.

The giants in their battle-gear

2980 Ran beside them, so we hear.

Wolfrat shared in the enterprise:

L. 2952 Diessen - a market-town in Upper Bavaria. 
An army of tremendous size

He led with him across the land

To join up with King Rother's band.

2985 He greeted with respect his lord,

As with his honor it did accord.

Because the clamor was so great,

A crowd began to congregate

When Constantine with his followers came

2990 Riding back to the court amain

At Constantinople in the town.

Hastily he asked around

Where might be his daughter fair,

Since he didn't see her anywhere.

2995 To this the queen his wife replied:

"O Constantine, be satisfied!

That nobleman so excellent

Who by the name of Dieterich went -

King Rother is his name, I swear!

3000 Now he has led our daughter fair

Westward over the sea with him.

How better wedded could she have been?

The clever fellow said to me

That he'll keep her for surety

3005 Until such time as he is paid

For having rendered you his aid.

Properly has he treated us.

It all was too ridiculous!

What exile ever had such might?

3010 Constantine, take this aright!

If an exile should come to your shore,

Take better heed than heretofore!"

When Constantine learned what had passed, His pleasant humor did not last.

3015 He started to weep and carry on so;

He beat his breast from heartfelt woe.

Said he: "Ah, madam, what grief is mine!

For my daughter I shall always pine

Whom Rother snatched away from me

3020 And led with him across the sea.

How dearly have I had to pay

For all that he did give away!"

From grief he fell into a swound.

Then in great numbers from the town 
3025 The citizens came hurrying nigh.

They raised aloft a mighty cry.

How Ymelot was helped thereby!

The man who had to look after him

Ran off to inquire about the din;

3030 Truly, he could not forgo

Learning why they were shouting so.

Then Ymelot did not delay:

He saved himself in a clever way.

While Constantine lay in a swound,

3035 Ymelot ran out of town.

In a vessel then he managed to flee

With a band of merchants over the sea

To the land of Egyptian Babylon.

Many a prince had later on

3040 To suffer for his sake grievous pain.

To the heroes too much trouble came.

When Constantine regained his wits,

Then all the folk, both poor and rich,

Started to shout in their dismay:

3045 "Ymelot has run away!"

"Woe is me!" said Constantine.

"Now take the treasure, mistress mine,

And share it with the valiant men

And help them to their homes again,

3050 So that retainers I shan't lack

In case King Ymelot does attack."

She didn't stint with the gold a bit:

She covered all their shields with it.

To every prince of high degree

3055 She gave of it right liberally,

And rewarded every honest knight.

(Just so today one strives aright

To earn for himself a glorious name.)

Homeward then they fared amain.

3060 When all that mighty gathering

Had left the presence of the king,

To him a minstrel then did say:

"Sire, I wish you health alway!

If you will reward me, Constantine,

3065 I'll bring your daughter back betime.

But for that we need to have a ship

L. 3025 A line is missing here. 
With all sorts of wondrous things in it:

Gold and jewels to please the eyes,

Genuine pearls of dainty size,

3070 Satins and silks for the ladies fair,

So that whoever would purchase there

Will find that we are well supplied.

And with us sixty knights must ride

Who shall keep hidden all the time.

3075 The precious stuffs, $O$ Constantine,

Will captivate the damsel so

That into the ship she'll quickly go

To take a look at my display.

Then with her we shall sail away!

3080 Now tell me what my reward shall be;

And if your offer pleases me,

Then I will gladly lose my life

If I don't bring you Rother's wife."

Said Constantine: "I thank you, sir!

3085 Now to my treasure I refer.

Help yourself, good friend, to it

Just as freely as you think fit.

I'm eager to see this journey made.

Be sure that you'll be well repaid!"

3090 At once the rigging on the ship

Was got in readiness for the trip.

The ruddy gold was brought aboard

At the behest of the mighty lord.

Rings and pins and bows for the hair,

3095 Stuffs for clothes exceeding rare

Constantine provided then

To get his daughter back again.

One began to bring the wares on board.

Everything was quickly stored.

3100 The clever minstrel and his crew

Sailed away without more ado

To the town of Bari by the sea.

At that time Rother had to be

In the Rhineland, so we're told,

3105 Together with his heroes bold.

There he saw that justice was done

To the widows and orphans every one.

As soon as the accursed Greeks

Had moored their vessel on the beach,

3110 The minstrel straightway went ashore

And brought back with him pebbles four 
Which he had found upon the strand.

How clever was the devilish man!

Now hear just what he wanted to do

3115 Or whom he wanted to sell them to!

Next morning at the break of day

The minstrel put upon display

A quantity of fabrics rare

In a stall that he had erected there.

3120 The burghers then came out on foot:

They were very eager to have a look.

They bargained there for silks and gold.

"For how much, friend, might that be sold?"

Nothing was so richly wrought

3125 But for a penny it could be bought.

The burghers then were ready to swear

That they had a fool to deal with there.

Whatever goods were on display

They bought from him without delay.

3130 One of them saw the pebbles then.

"How much for one of those, good friend?"

Then he said that it might not be sold

For less than a thousand pounds of gold

Of such an excellent quality

3135 As might suit a lady of high degree.

In reply to this the burgher said:

"You're only trying to pull my leg.

You must be one of the Devil's own.

It looks to me like a common stone!"

3140 The minstrel answered: "Now I swear

That to this stone you are not fair!

You ought not to abuse it so.

For many things it's good, I trow.

If a queen should take it in her hand

3145 It would shine out over all the land.

Supposing that someone had died

And had not yet been laid aside:

If he were stroked with this stone here

He'd rise up quickly, never fear!

3150 There is no one so crippled or lame

But he would quickly walk again

If the queen were to touch him a single time

With this most excellent stone of mine.

But she has to do it in the ship,

3155 Else he will have no good of it.

If we had a cripple now, my lord, 
And the queen were willing to go on board, Then if what I have been telling you Should turn out to have been untrue,

3160 You may bid your men take hold of me And hang me from the nearest tree."

Then to the minstrel said a knight (Great in Bari was his might):

"I am the father of children twain

3165 Who for a year now have been lame, So that we must carry them everywhere.

Now to the queen I will repair.

Perhaps of her goodness she'll agree

To cure them of their infirmity.

3170 If they are aided by your stone

So that they're able to walk back home,

With so much wealth I'll gladly pay,

As you may be able to carry away."

"If I am lying," the minstrel said,

3175 "Let your men cut off my head!

But I don't fear such a penalty:

My life is much too dear to me."

Then he gathered all his kinsmen round -

Sixteen merchants of the town -

3180 And to the queen he did repair.

He was welcomed by the lady fair

In a manner very debonair -

Just as if he were someone

Who from a princely line did come.

3185 Then he hastened to entreat her

In the name of good Saint Peter

To do whatever she could to save

Two victims of an ailment grave.

"They are my children, gracious dame,

3190 Who for a long time have been lame.

A ship is lying in the bay

To which I'll bring them straight away.

Excellent stones are there on board

By which the sick can be restored.

3195 If you were to take one in your hand,

It would shine forth over all the land.

Supposing that someone had died

And had not yet been laid aside:

If you should stroke him then with it,

3200 At once he'd rise up perfectly fit.

There is no one so crippled or lame 
But would be quickly sound again, As that lad gave us to understand Who brought these pebbles to our land.

3205 He says, if what I'm telling you

Should turn out to have been untrue, Then it will be all right for me To hang him from the nearest tree. For God's sake try it, gracious dame!

3210 A rich reward you well may claim If you can heal those sons of mine Who have been lame so long a time. What pain it brings to wretched me When I behold their misery!"

3215 Now hear the answer the queen did make! "Since you entreat me for Jesus' sake, I find I must agree to it.

Let them be carried to the ship!" At that time Lupold was away.

3220 Then twenty good knights did not delay: They went to the ship with the lady fair. Quickly one brought the sick lads there, Whose health was going to be restored. As soon as the lady stepped on board, 3225 "Let us be off!" the minstrel cried.

"To the land of Greece it's time to ride!

That woman for whom we made this trip Behold her standing in the ship!" Then all the Greeks with one accord

3230 Swiftly made their way on board.

They threw the sick lads back on land.

No one got stroked by the good queen's hand.

Those who were waiting on the dame

Were led by the Greeks across the main.

3235 Now take a look at that devilish man -

How he had succeeded with his plan!

The Greeks sailed quickly on their way.

The lady bade the minstrel say

At whose behest he and his band

3240 Had journeyed thither to that land.

"In truth, it was Lord Constantine,

Your dear father, mistress mine,

Who ordered us to cross the sea."

"Alas, King Rother, woe is me!"

3245 The wretched woman cried aloud.

"Henceforth upon your body proud 
You will inflict the direst pain.

For your sake I shall do the same."

The lady was in a pitiful state.

3250 The minstrel had her carried straight

To Constantinople Town.

How quickly then the news spread round

That success had crowned their prince's plan!

Then all the burghers to a man

3255 Welcomed the queen with one accord.

Quickly Constantine went on board..

He took his daughter by the hand

And escorted her onto the land.

He hugged her and he kissed her.

3260 How sorely he had missed her!

Her mother drew nigh weeping :

She did not like this meeting.

No matter what the old queen said,

Her daughter only bowed her head.

3265 Constantine was full of cheer.

To all her words he lent no ear.

He let his daughter hold her peace

Until she had enough of grief.

The news began to spread around

3270 Everywhere in Bari Town

That the lady had been snatched away.

Then they feared lest Rother would make them pay.

Then all the townsfolk, men and wives,

Hoped by fleeing to save their lives.

3275 Then Lupold hurried to them anon

And cheered up the downhearted throng.

He pleaded with them not to flee

And said that he could guarantee

That Rother's anger would abate,

3280 So that he would not seek to take

Revenge on anyone for the blame,

Nor say anything to cause them shame.

The wealthy burghers all alike

Fell at the feet of the worthy knight.

3285 They promised him that they would do

Whatsoever he asked them to -

They depended fully on his aid.

Truly, they were much afraid!

Then said the very worthy knight:

3290 "God will rescue us from our plight.

So great is my master's loyalty, 
We may yet be saved if God so decree." Seven nights from that same day

Rother came with great array

3295 Riding back to Bari Town

And heard some news that cast him down.

The faithful Lupold went apace

And took his stand in the foremost place.

Then said the hero unafraid:

3300 "Noble lord, I have betrayed

The confidence you showed in me.

Your wife is back beyond the sea!

The Emperor Constantine has, alas,

Brought that cleverly to pass.

3305 Your anger, sire, must be so great

That now my life you'll want to take.

My brother Erwin is here with me.

He lay in Greek captivity

On your account a weary time

3310 And forgot how it was for the sun to shine.

Now give us for this our just reward

By sparing these people, worthy lord.

They have been blameless all along;

They have not done you any wrong.

3315 'Twas I who encouraged them to stay

When they were bent on running away.

I urged them all to tarry

Here with me in Bari.

The blame is mine alone to bear.

3320 Sentence me now, hero fair,

As is only proper and right.

Tell me why an honest knight

Should have any further need of wealth

If he has not kept faith with himself.

3325 Now since I haven't done so,

Out of this world I'm ready to go."

Now hear how the mighty Rother spoke,

Who had been dealt this grievous stroke!

There before that noble band

3330 He took Sir Lupold by the hand

And paid him honor with a kiss.

"Cousin, think no more of this!

You have no reason to be dismayed.

There still lives many a lovely maid.

3335 But if the lady was meant to be

A source of happiness to me, 
Then it may finally come out right.

No more of this, most worthy knight!

If you were now to feel my rage,

3340 That would be indeed a sorry wage

For the service you often rendered me.

You lay in Greek captivity

Eighteen months, $\mathrm{O}$ hero fair,

And of your life you did despair,

3345 And with you many a hero true.

If I were ever wroth with you,

Like Judas I should be to blame,

Who condemned himself to eternal shame.

Now tell these burghers standing here

3350 That they have nothing at all to fear."

Many an honest fellow saw

How the king conceived the law

And how his anger had been meant.

Thereupon Sir Berchter went

3355 Just as politely as he could

To where the noble Rother stood,

And burst out laughing from delight.

"May God allow me to requite

The mercy you have shown my son.

3360 For my poor sake 'twas surely done.

You have today, $\mathrm{O}$ hero bold,

Renewed the excellent way of old

Which by your father were highly prized

As long as he was still alive.

3365 If now my body were only so

As it was fifty years ago,

I'd repay this honor you have done

As well as many another one.

But now, alas, that may not be!

3370 Constantine has recently

Been most unkind to some of you.

Never forget that, heroes true -

You who here before us stand.

$\mathrm{He}$ is, in truth, a devilish man!

3375 Rother, my advice would be

To fare in force across the sea.

This beard of mine is not so grey

That here at home I'd consent so stay!"

"Where are now," said Asprian then,

3380 "My master Rother's loyal men,

With whom it was his pleasure 
To share his wealth and treasure -

Now that he needs them in his plight?"

One saw then many a worthy knight

3385 Push his way into the ring.

And the right to many a great estate.

And so they did not hesitate

To swear unto their mighty lord,

As with their honor it did accord,

3390 That if he ever were bestead

They'd fight for him till they were dead.

In a loud voice Widolt shouted then:

"Here is a splendid band of men!

They're not afraid, it's plain to see,

3395 Of losing kin and property,

Rother, to preserve your fame.

We'll help you come across the main!

Whoever renders service true

Will be rewarded well by you.

3400 Constantine's followers were not slow

To deal us a most grievous blow.

If we don't repay it 'twould be a shame.

My trouble would have been all in vain."

Then up spoke Wolfrat, a hero proud:

3405 "Seeing that Widolt now has vowed

That we shall help His Majesty

To make a trip across the sea,

I shall lead forth from my own land

To join the rest a mighty band

3410 Of heroes dauntless in the fray -

Twelve thousand knights in fine array.

I swear that I shall help maintain

The name of Lupold free from shame.

The gentleman and I are kin.

3415 It is indeed a Christian thing

When brothers and cousins all agree

To live together honorably.

Whoever abandons one of his kin

When things aren't going well for him -

3420 Had he left a countryman in the lurch,

His honor would be less besmirched.

The noble Rother did behave

As well becomes a hero brave:

L. 3385 One or more lines are missing here. 
After my father had been banned,

3425 He helped win back for him his land.

By him Duke Elbewin was slain

(From the region of the Rhine he came

And he was, in truth, a terrible foe

Who often caused us grievous woe).

3430 Because of the love we bear him now,

Cousin Lupold, I do vow

That you can count upon my aid

As long as I can swing a blade!"

Thus spoke proudly in the ring

3435 The worthy lord of Tengeling.

The valiant Lupold then did say:

"Vassals and kinsmen, where are they?

Verily, we must cross the main

To the Emperor Constantine's domain.

3440 Cousin Wolfrat, set out now

In accordance with your vow.

Ride home now to your domain

And call up many a doughty thane.

And I shall likewise lead apace

3445 Young lads to the gathering-place

From the city of Milan,

Which I have as King Rother's man -

Twenty thousand keen to fight,

Clad in hauberks shining bright.

3450 Let us set a time, I pray:

Twelve weeks from this very day,

Here at Bari by the sea."

Then many a lad swore willingly

An oath unto their mighty lord,

3455 As with their honor it did accord.

The Duke of Meran then did swear:

"Twenty thousand heroes fair,

Rother, you shall have from me

To help you come across the sea.

3460 And this I furthermore do say:

If Constantine should cross my way,

My sword will deal him such a blow

That he will never recall, I trow,

How dear his daughter was to him

3465 (If I die before I do this thing,

Let no man hold it against my name);

For he made me suffer grievous pain.

I feel even now the ancient woe 
When I think how he tortured Lupold so."

3470 The noble warriors bedded down

There at Bari in the town.

When morning came they quit the strand.

Then princes hurried through the land.

Lupold journeyed to Milan,

3475 Berchter hastened to Meran.

A doughty youth then did not stay:

Towards Tengeling he made his way.

Wolfrat it was, a hero bold.

Now our story will unfold

3480 How these gentlemen restored

Honorably to their lord

A lady of surpassing worth,

Who to young Pippin then gave birth,

From whom Karl later came to us

3485 And also a maiden most virtuous.

(Saint Gertrude is the one I mean:

At Nivelle her chapel can be seen,

And she helps the sinner willingly

If penitent he prove to be.)

3490 In view of such facts no one may say

That our poem lies in any way.

The appointed day did soon draw near.

Many a man then donned his gear

In readiness for the great campaign

3495 Which had been vowed in Rother's name.

An ancient man then made his way

Across the land in fine array.

To Bari he came riding

To spread the welcome tiding

3500 That many a lad was coming there.

He rode upon a courser fair.

Upon the shield of the hero bold

Was to be seen a boss of gold.

The shield was made in such a way

3505 That it caught up the light of day And sent it back with a blinding glare.

He wore a tight-fitting hauberk there.

Down to his belt his beard did hang.

There never lived another man

L. 3486 Saint Gertrude - especially honored in the Rhineland; actually the daughter of Pipin of Landen.

L. 3487 Nivelle - in Belgium. 
3510 Who was deserving of greater praise

Than the noble Berchter in those days.

Rother went to greet the lord,

As with his honor it did accord.

Likewise did Sir Asprian,

3515 And so did Widolt, the valiant man.

Then Berchter said: "Ah, noble King,

Reward me for the news I bring!

From this time on be of good cheer!

Many good lads are riding here.

3520 Now take the burghers with you, pray,

And ride from Bari straight away

Out onto the lovely strand.

There you will see a mighty band

Before the sun sinks in the west.

3525 I have been sent ahead of the rest

That I may let you know, O King,

How great an army we do bring."

Along with Widolt and Asprian

The mighty Rother then began

3530 To summon the burghers to their side.

From Bari then they all did ride

Out onto the lovely strand.

The whole horizon from there they scanned.

Then they espied beneath the sky

3535 A mighty army riding by,

All in armor fully clad.

Many an undaunted lad

The faithful Lupold was leading there.

He held aloft a banner fair.

3540 Whenever the wind tossed its folds about,

The reddish gold would then flash out,

So that it seemed to every eye

As if it were lightning from the sky.

Then all the burghers to a man

3545 Who had assembled on the sand

Said: "Gracious God, what's this we see?

Who can all those people be

Riding behind that banner fair?"

Then Berchter said to Rother there:

3550 "My lord, give ear to what I say!

Your fellow-warriors ride this way.

The faithful Lupold it must be,

Bearing that banner so splendidly.

(His county he does earn today, 
3555 So that you may grant it without dismay.)

Most artfully are its colors blent.

Behind it rides a regiment

Of heroes twenty thousand strong

Whom nothing can resist for long.

3560 For your sake I and my sons agree

To lead these men across the sea."

Then at the side of Lupold's band

There shone in rivalry through the land

Emeralds and sapphires, too.

3565 Of bachelors a mighty crew

Came riding behind a youthful knight

Who carried a banner snowy white.

Wolfrat of Tengeling was his name,

And with him fifty thousand came,

3570 Warriors most deserving,

From honor never swerving.

Silken stuffs and filigree,

The very best embroidery

Which anyone did ever glimpse

3575 In any campaign before or since -

On horses it all was transported there.

In silken mantles passing fair

The lads from Bavaria rode their way.

Never shone the light of day

3580 Upon so many helms, we're told,

Artfully adorned with gold,

As the hero Wolfrat brought with him

To lend support to his noble kin.

(Bavaria still is known, in truth,

3585 As the home of many a dapper youth.)

As soon as all that doughty band

Had ridden out onto the strand

And pitched their tents beside the sea,

Then Rother came there speedily

3590 And welcomed Lupold, the noble lord,

As with his honor it did accord,

And also Wolfrat, the hero true,

And many another warrior too.

He greeted all of them to a man.

3595 Then said the giant Asprian:

"Alas, King Rother, woe is me!

That I am now compelled to be

Standing here without a band

Of warriors from my native land - 
3600 That's because they live so far away.

I am alone to my dismay!"

"Be silent, my lord Asprian!"

Said to him Widolt, the valiant man.

"There in Constantinople Town,

3605 The citadel of great renown,

Not a house-door will there be

Before which you might station me

Where, if someone is found therein,

Such a battle won't begin

3610 That not before the Judgment Day

Could it be stopped in an honorable way."

The nobles stayed there overnight.

As soon as morning showed its light,

The noble Berchter did not wait:

3615 He took the hand of Lupold straight

And that of the doughty Lupold, too,

And set out thence without ado.

Erwin carried each man's sword

At the behest of his noble lord.

3620 Then the three advised the king

To pick out from the gathering

Thirty thousand valiant men

And send the others home again;

And with his treasure not to spare

3625 But give to all who wished a share.

When they had given their counsel true,

Swiftly Asprian withdrew

And came back with the king's red gold,

As Berchter had bidden the hero bold,

3630 And handed it out to the warriors then:

He helped them to their homes again.

Then Rother led from his domain

Thirty thousand across the main.

Vessels numbering twenty-two

3635 Were loaded for the heroes true.

Then from the port sailed many a son

Whose father to Bari had never come.

The sails roared loudly in the wind.

Over the water the vessels skimmed

3640 And within the span of six weeks came

Journeying across the main

To Constantinople Town,

The citadel of great renown.

Below the town a mile or more, 
3645 Where woods and hills meet by the shore,

There Rother's men began to lead

Onto the land full many a steed

And bring them under the trees so fair,

So that no one became aware

3650 Anywhere in the Greek domain

Just how many a doughty thane

Was standing in the lovely wood

Along with Rother, the hero good.

(His was the old propriety

3655 And the worldly piety

Which every single man today

Towards his master should display:

Then never could the Devil

3660 As soon as that intrepid band

Had left the vessels for the land,

They went at once to take their ease

Underneath the lovely trees.

Then did the mighty Rother say

3665 In an extremely prudent way:

"Hear me, vassals and kinsmen mine!

I now shall go to Constantine

In the disguise of a wayfaring man

Who must beg for his food from land to land.

3670 So may I learn what's going on."

The youthful Wolfrat said thereon

(He was the lord of Tengeling):

"Do not go alone, O King!

Berchter is a prudent knight

3675 And often has advised you right.

And if, my lord, you would maintain

The honor due your noble name,

The faithful Lupold you'll also ask

To help you carry out this task.

3680 Now take this excellent horn of mine:

For all of us it shall be a sign.

The Greeks, in truth, are very clever;

And if they should learn of your endeavor,

3685 "Verily", said Asprian then,

"As soon as we hear you blow your horn,

The citadel we'll swiftly storm.

No matter how large the town may be,

I swear by all that's dear to me 
3690 That before whatever street I stand And with me Widolt, the valiant man, That will become the narrowest road Along which anyone ever strode!"

The heroes then did not delay:

3695 They slipped into pilgrims' clothes straightway.

The worthy Berchter of Meran

Along with Lupold, the faithful man,

Went at the side of the mighty king

And left behind the gathering.

3700 Then towards them rode a warrior good

Who'd been watching from the edge of the wood.

The mighty Rother in disguise

Greeted him in courteous wise

And asked the gentleman to say

3705 Whether any news had come his way.

"In me you see a wretched man

Who must beg for his food from land to land.

Now tell me, dear sir, something new!

A needy pilgrim is asking you

3710 Who has to cover many a mile

Suffering sorely all the while.

And so the poor man in his need

Must often to the court proceed.

There one asks the wayfaring man

3715 To tell whatever news he can.

For God's sake tell some news to me!

Well rewarded you will be."

The worthy hero replied thereto:

"Plenty of news I have for you.

3720 Here in Constantinople Town,

The citadel of great renown,

A very noble exile dwelled,

For splendid manners unexcelled.

(To this I always can attest,

3725 For he gave me nothing but the best.)

The princes all did love the youth.

He gave to them more gold, in truth,

Than ever before fell to the share

Of anybody anywhere.

3730 The doors of his court stood open wide

To let the poor and the rich inside.

They soon found in the hero true

A father and a mother, too.

His whole ambition was but to give. 
3735 He did not care at all to live With any kind of surfeit.

He waged a war against it.

Both night and day he brought it lower.

If one asked for a thousand pounds or more,

$3740 \mathrm{He}$ gave it away as easily

As if two pennies it might be.

Now tarry, sir, and I shan't fail

To let you hear the rest of my tale." Rother thought it lots of fun

3745 To hear what he himself had done.

The warrior went on straightway:

"About this lord I've more to say!

We loved him for his gentle ways.

A man deserving of greater praise

3750 Because of his goodness was never seen

Anywhere on earth, I ween.

I don't know of anyone at all

Who would be able to recall

All of the hero's excellent deeds.

$3755 \mathrm{He}$ attended to the exiles' needs.

The wretched lads were bathed and dressed

And served at the table at his behest.

Whatever was his he gave to them there.

He didn't care who took his share.

3760 He led so many a doughty youth

That under the heavens, in very truth,

No exiled man was able to boast

Of having gathered a greater host.

He proved his valor for all time

3765 By saving the mighty Constantine

When he was in a dangerous spot.

He captured the Emperor Ymelot,

A terrible paynim, so they say,

Who received the homage every day

3770 Of princes two-and-seventy strong

From the land of Egyptian Babylon.

Joyfully our army then

Began to journey home again.

The king then sent the valiant man

3775 Ahead as an envoy to our land

That he might tell to the ladies fair

All that he had accomplished there.

Now here in Constantinople Town,

The citadel of great renown, 
3780 There was residing a maiden fair With whom no other could compare. For her he suffered grievous dole And with decorum achieved his goal So that the maiden did not fear

3785 To run with him away from here Before the army came back home. He took her in payment for his own And traveled westward over the sea. The King of Rome he proved to be,

3790 Rother, a man of noble mind And to all of us extremely kind. Now, good pilgrim, you shall be told How one paid back the hero bold." Rother wished to go from there.

3795 Then said to him the hero fair:

"Tarry a moment, pilgrim, do! Important news I have for you. When Constantine came back one day, The paynim managed to run away.

3800 The king dispatched some envoys then To win his daughter back again.

They stole her from Rother cleverly And brought her back across the sea. Then Ymelot, the paynim lord,

3805 Came riding with a mighty horde Hither to this Grecian land, And burned and pillaged on every hand, And captured the Emperor Constantine, That very hateful lord of mine.

3810 Then Constantine redeemed his life By handing over Rother's wife To that king so fierce to look upon From the land of Egyptian Babylon. Wedded to his son she'll be,

3815 As you this very night can see. Thirty kings have settled down At Constantinople in the town Together with an army strong From the land of Egyptian Babylon.

3820 Rother's wife is among them there And keeps chastising her body fair On account of her very grievous plight. Now may our Savior in His might Send Asprian to us anon 
3825 Before this day has passed and gone."

To this the nobles said "Amen!

Upon God's grace it does depend."

Swiftly then the hero good

Galloped off into the wood,

3830 Wringing his hands as he rode his way

And sorely weeping in his dismay.

In such wise did that worthy knight

Bewail the damsel's grievous plight.

Into the city Rother hied.

3835 Berchter went at his master's side

And warned him not to be too bold.

The mighty Constantine, we're told,

Along with many another lord

Was seated at a festive board

3840 Within a hall most fair to see.

Great was the noise of revelry

In front of the princes thirty strong

From the land of Egyptian Babylon.

Then Rother crept with sly design

3845 To the table of King Constantine.

Beside the king sat Ymelot's son

(His name was Basilistium).

Next to him sat Rother's mate

And did not cease to bewail her fate.

3850 Then said the mighty Constantine:

"Stop your weeping, daughter mine!

I had a dream last night of you

(You can believe that I speak true)

How a falcon flew here to our strand

3855 All the way from the Roman land

And carried you back across the sea."

Rother then crept stealthily

Under the table with his men,

So that no one was aware of them.

3860 And so he could overhear everything

That the guests were speaking with the king.

The princes then began to boast

About the strength of the paynim host.

"If Rother should show up," said they,

3865 "We'd see that he was drowned straightway

Or otherwise slain shamefully -

How angry then would Widolt be!"

To them the queen replied: "I vow

That if our Lord were to send him now 
3870 Here among you heroes true,

He would belabor some of you

So that even after a sevennight

The pain would not have vanished quite."

Rother moved closer without being seen

3875 Upon the footstool of the queen.

Then he took a golden ring with care

And passed it to his lady fair.

(Letters were engraved therein

Which spelled the name of the mighty king.)

3880 As soon as the lady became aware

That her mighty lord was hiding there,

Then she began to smile anon

And told her mother thereupon

That Rother had, without any doubt,

3885 Come from Bari to help them out.

By Constantine the smile was seen.

Now hear how he addressed the queen:

"Blessings on you, daughter dear!

Now my heart is filled with cheer."

3890 The splendid dame replied thereto:

"In very truth, I now must rue

That with you I was ever wroth.

"Tis the very last time, upon my oath!"

Ymelot said thereupon:

3895 "Lady, you need not put on.

It's my belief that your smiling now

Will cause us heartfelt grief somehow.

When it is finished there will be

Wringing of hands, in all verity.

$3900 \mathrm{Be}$ on your guard now one and all!

Somewhere here inside the hall

The hateful envoys tarry

Of Rother, King of Bari.

If anyone doubts what I have said,

3905 To him I'm ready to give my head!"

Thereupon said Ymelot's son

(His name was Basilistium):

"Just now I saw a handsome ring

Which by your daughter was slipped, $\mathrm{O}$ King,

3910 Into the hand of the ancient queen.

Somewhere in the hall, I ween,

The mighty King of Rome does hide,

Though I don't know how he got inside.

You can depend on what I say!" 
3915 Then Constantine said right away:

"Before the door I shall command

Twelve of my men to take their stand

So that they may properly recognize

If here among us are any spies.

3920 Should Rother now be hiding here, We'll quickly find him, never fear!

But if he were to show his face, It surely would bring less disgrace Upon the mighty king, I vow,

3925 Than if we had to search for him now

As though he were a runaway thief.

It doesn't become him in the least

That he refuses to appear,

Even though we know that he is here."

3930 Rother pondered secretly

What his conduct now should be.

To him the Duke of Meran said:

"Let each of us now show his head

In honor of the Heavenly King

3935 And all His mighty following,

So that of His benevolence

He'll quickly come to our defence

Against the heathens in this hour.

In token of His mighty power

$3940 \mathrm{He}$ bade that Moses undertake

By way of the Red Sea his escape

With the children of Israel.

Not one of them was forced to dwell

Upon that awful water's ground.

3945 Thus are good and evil bound

By our Heavenly Father still,

Even though one resist His will.

Provided we have always been

Wholly pure and free from sin

3950 In our Heavenly Father's sight,

He'll not forsake us in our plight.

Now I swear by Saint Aegidius' name

That here no longer will I remain!"

In this wise Berchter spoke to them.

3955 From underneath the table then

Slyly crept the gentlemen.

The noble Rother walked ahead.

"Verily, I am here," he said.

"Whoso desires may look on me!" 
3960 Then all the princes equally

Threatened to slay him right away -

For which some later had to pay.

Then said the Emperor Ymelot's son

(His name was Basilistium):

3965 "Rother, were it up to me,

I'd have you thrown into the sea.

'Twas you who took my father alive-

Because of which you shan't survive!

Your life you must prepare to lose,

3970 Howsoever you may choose."

"Upon my word", said Constantine,

"A shameful death would suit him fine!"

To this the mighty king did say

In an extremely clever way:

3975 "Even though you freed me now,

I still could not survive, I vow.

Do you see those mountains over there,

Standing in front of that forest fair?

That is where I wish to hang.

3980 Your followers you should command

To give you all the help you need -

You yourself shall do the deed.

In my domain it is only right,"

Went on to say the honest knight,

3985 "That whatsoever a prince befall,

Another prince must see it all.

Here is a mighty company,

Thirty princes, verily!

Thither with you they shall come

3990 And with me they will have their fun;

And so you will enhance your name.

Then Ymelot's men will all proclaim

How you avenged yourself on me."

The lord spoke very cleverly!

3995 Close by the spot where he would hang

Was lying his intrepid band.

He had picked out the very spot

To which Sir Asprian had got.

Ymelot bade the princes strong

4000 From the land of Egyptian Babylon

To seize King Rother straight away:

He wished to hang him without delay.

"In truth," said Constantine, "I should like

To be of assistance if I might, 
4005 So that he doesn't escape from us.

That ancient fellow with the beard

Is by the people greatly feared

When through the land he leads his men.

Now that we have all three of them,

4010 We probably shan't have to fear

Lest the Roman folk should ever hear

Whither their mighty king did wend

Or how he happened to meet his end."

The awful moment had come round.

4015 Rother's hands were quickly bound

(That was the work of Ymelot's men).

How bitterly the young queen then

Filled the air with her complaint.

From grief she fell into a faint.

4020 How very great was her travail!

Then there began to weep and wail

The ladies fair on every side:

Their flowing tears they could not hide.

No need was there for one to ask.

4025 Everybody was aghast

At the noble Rother's plight.

(Later the good Lord in His might

Helped Count Arnold rescue him

From Ymelot, the terrible king.)

4030 The news that Rother was to hang

Quickly spread from man to man

In Constantinople Town,

The citadel of great renown,

Till it came to the ears of the heroes fair

4035 Who from many a land had gathered there.

They all began to weep full sore

As they ran down towards the shore.

They raised their voices in a shout.

"Amighty God," they all cried out,

4040 "How could You let it come about

That fettered now that man should be

Who saved us all from misery?"

A nobleman was living well

On the thousand pounds, so we hear tell,

4045 Which Rother had given him for his share.

Seven hundred warriors fair

L. $4005 \mathrm{~A}$ line is missing here. 
Paid him service in the town:

To him in fealty they were bound.

Arnold was his name, we're told,

4050 And he had plenty of silver and gold,

Which he took pleasure in giving away.

Twelve hundred men in full array

He led towards the shouting then,

And ordered all his noble men

4055 To liberate with their own hands

The mighty Rother from his bands.

"The lord is standing fettered there.

If he should hang today, I swear

That we will never know any peace.

4060 Nor will the Romans ever cease

From mourning the loss of the hero true.

Never will any one of you

Hear of a man who was his peer.

Today we should repay him here

4065 For having deigned to set us free

From lives of direst misery.

Up, good lads, and don't delay!

Put your trust in God this day

And come to the aid of the noble lord.

4070 Heaven will be your reward."

Thus spoke Arnold, a worthy knight.

"Truly, we defend God's right.

If anyone today is slain,

Eternal bliss his soul will gain.

4075 Let's kill these paynims one and all!

May Saint Aegidius recall

And Saint John the Baptist, too,

That never lived a king more true

Than the noble Rother anywhere -

4080 To the truth of which I'm ready to swear!"

Many a hero unafraid

In coat of mail was soon arrayed.

Truly, they were a splendid sight!

Five thousand warriors well-bedight

4085 Were ready to perish in the fray

If Rother might be saved that day.

Forth from Constantinople Town,

The citadel of great renown,

Thirty princes marched along,

L. 4076 Aegidius - a saint much revered in the Rhineland. 
4090 Followed by a mighty throng.

At their head went Basilistium

(He was the Emperor Ymelot's son)

And led King Rother along the way:

He wished to see him hang that day.

4095 Then there was raised a mighty cry

As they led the hero forth to die.

To the gallows-place there went along

Cumans a hundred thousand strong,

And as many of the paynim horde.

4100 How deeply that did grieve the lord!

Count Arnold showed no sign of fear.

He bound a reliquary to his spear

Which in the church he had obtained.

Then calling on our Savior's name

$4105 \mathrm{He}$ led his followers from the town.

How eager was he to reach open ground!

Fighting-men five thousand strong

In shining armor he led along.

When Ymelot espied this host,

4110 This is the way he began to boast:

"Ha! take a look at those warriors there!

They thought to give us all a scare.

I'll wreak my wrath on every one.

Alive from here not one shall come!"

4115 The paynim army soon drew nigh

To the spot where Rother was to die.

On every side they raised a din.

"Now build the gallows high for him!"

This moved the heroes to the core.

4120 Many of them wept much more

Than they had ever done before.

Rother's need was very sore!

The valiant Arnold then began

To call on many an exiled man.

4125 "Worthy lads, give ear, I pray,

To what we're fighting for today.

Two rewards we have in sight:

All the more gladly should we fight!

The first reward is fair indeed:

4130 The Kingdom of Heaven will be our meed.

If any of you shall die today,

L. 4098 Cumans - an Asiatic nomadic people which invaded Europe around 1045; known among the Slavs as Polovtsi. 
His soul will be released straightway

To another life of lasting bliss.

What gift was ever better than this?"

4135 Now hear about the second reward!

If you shall save our faithful lord,

He'll take you with him overseas

And assure you of a life of ease."

His eyes began to dim with grief.

4140 Strengthened by the true belief,

They fell upon the paynims then

And slew a mighty host of them.

The armor of the paynim throng

Proved to be exceeding strong:

4145 The suits they wore were made of horn.

On high the relic then was borne

Before the eyes of the heroes bold.

Into the thick of the fray they rode.

The relic was always in the van.

4150 In God confided every man.

So fiercely did the heroes fight

That nothing could withstand their might.

The infidels were driven back

Before the force of their attack.

4155 From the gallows-place there then withdrew

The paynims and the Cumans, too.

Verily, they were sore bestead!

Many a hero lay there dead.

Then Arnold did not hesitate:

4160 He gave from his hand his standard straight

And drew a sword (its name was Mal).

Never had any steel at all

Been made so rigid or so hard

That it wasn't able to split apart.

4165 Because of this he was able to slay

Six of the princes right away.

To whomsoever else he came

The hero quickly did the same,

Until he had rescued the noble man

4170 Together with Berchter of Meran

And also Lupold, a hero fair,

Whom they had wanted to string up there.

If on our story we can rely,

No one could keep on them an eye.

4175 Those who wanted to wreak them woe

Said that God had willed it so. 
As soon as Rother became aware

That Arnold was standing beside him there,

He cried out to the valiant knight

4180 In a manner that beseemed him quite:

"Cut asunder now these bands,

Doughty warrior, from my hands,

And when upon my horn I blow

Many more will be laid low

4185 Than have been up to now, I swear!

To us will Asprian soon repair."

As soon as the warriors heard his name,

How happy all of them became!

Eager were they for the fray.

4190 Not a thought did they give to running away.

Truly, they were a valiant band!

At that time there were upon the strand

Seven heathen princes still,

With eighty thousand to do their will.

4195 Loudly a horn resounded then

Over the mountain and the glen.

It had been blown by Rother's man,

The faithful Lupold of Milan.

Then in a loud voice Asprian said:

4200 "God knows, my master is sore bestead!

Wolfrat, don your armor straight:

I think your cousin's need is great.

Of Rother I shan't speak at all;

But if Sir Lupold were to fall,

4205 His loss we'd never cease to rue.

No hero ever was more true."

Widolt hurried from the wood

Just as swiftly as he could.

How his hauberk gave a clang

4210 Whenever over a bush he sprang!

After him came Asprian.

The twelve ferocious giants ran

Over paths both good and bad.

Accompanied by many a lad,

4215 Wolfrat of Tengeling came with speed:

A splendid army he did lead

Forth from the middle of the wood.

To Rother were pledged the heroes good.

Many a lad in full array

4220 Hurried there along the way.

On every side could be heard the din. 
From the gallows then they rescued him And listened to how the earth did shake. Two terrible giants full of hate

4225 Were coming thither on the run.

Of them Asprian was one.

The other was Widolt, a hero bold.

(Across the land shone forth the gold

Which adorned the margin of his shield.)

4230 From Ymelot was not concealed

What Rother had in mind for them.

How gladly would he have run off then!

Many a paynim started running.

Asprian set the wind a-humming.

4235 Towards him Rother made his way.

"Listen, bold hero, to what I say!

The giants mustn't harm a hair

Of those who are standing with Lupold there.

Those gentlemen are the very same

4240 Who helped me to avoid great shame.

In fetters I was forced to stand.

Then I was just about to be hanged

By those princes so fierce to look upon

From the land of Egyptian Babylon.

4245 Now I don't care how they're made to pay.

I shan't interfere in any way!"

Then Grimme cried for all to hear:

"They'll never get away from here!"

The giants ran onto the battle-ground.

4250 From the host there rose a mighty sound.

Asprian began to slay

Whosoever crossed his way.

By Widolt not a word was spoken

Until to bits his club was broken.

4255 The savage fellow drew thereon

A club most awful to look upon.

Into shreds were cut the horses then

Which were lying on the dying men.

From many a wound the blood did gush

4260 When the valiant Wolf rat with a rush

Hurried into the midst of the fight

Along with many another knight.

The doughty lads performed that day

Such deeds of daring in the fray

4265 As will forever enjoy renown,

Because the facts have been written down 
Concerning all that company

Who almost had been forced to flee.

The seven princes turned away

4270 From the center of the fray.

Truly, they were terrified!

At one of them did Erwin ride.

He struck the devilish man a blow

From his shoulder down to the saddle-bow

4275 All the way through his horny attire.

Thus did the hero avenge his sire.

Five of them they hanged straightway.

How dearly were they made to pay!

The heathen slaughter then began.

4280 Upon the field lay many a man.

Whenever one cried out in pain,

Widolt rushed at him amain

And dealt him such a vicious kick

That he never did get over it.

4285 They had good reason to feel dismay

And to await the Judgment Day,

Because not one did the giant spare.

Ymelot, who had led them there,

Was bidden then to go his way

4290 And set out thence without delay,

So that at home he might proclaim

By whom his followers had been slain.

A hundred minstrels, so we're told,

Had come there with the paynims bold.

4295 The hero Grimme had them bound

And stretched full-length upon the ground.

A thorough switching they got that day;

For Ymelot they were made to pay.

Then one of the minstrels managed to flee

4300 Who had fled from Widolt previously.

To Constantine he came apace,

As fast as he was able to race.

Then all the princes questioned him

About the reason for the din

4305 Which they heard coming from the field.

"Important news shall be revealed!

The prisoner has gotten clear.

With an army they are riding here.

Whoever would not hang today

4310 Had better not stay here, I say!

The hero Widolt is giving away 
Over yonder food and pay

To many an unbelieving wretch.

Upon the ground I was made to stretch.

4315 Then I was lashed with whips and shorn.

My life I almost had forsworn!

But this I truly can report:

For bruises of the finest sort

Widolt's club can't be outdone.

4320 They've hanged Prince Basilistium.

They're not content to chop off a foot;

They help you out of this life, to boot.

Now the Devil is making a fool of me!

Why do I show such courtesy

4325 And stand here talking so long with you?

Question some other fellow, do!

Whosoever is seized today

Forevermore will have to pay!"

Quickly then they all took flight.

4330 Brooding over his grievous plight

Sat Constantine, the mighty king.

How shameful all this was to him!

Our story now goes on to say

How the lads from Rome began straightway

4335 To pull back all their forces

And catch once more their horses.

Then had the wrath of Wolfrat made

Bloody traces with his blade,

Deep incisions with his spear,

4340 Cloven through the helmet sheer

Of many a sorely wounded man.

By means of his undaunted hand

The hero sent upon his way

Many a worthy lad that day

4345 To an unpleasant reckoning.

(He was the lord of Tengeling,

And came from an illustrious clan -

A rich yet not a haughty man,

And of a very prudent mind;

4350 And so to his family he left behind

The right to bear a princely name

As long as this world does remain.)

In front of Arnold took his stand

The worthy Berchter of Meran.

4355 Beside the latter Wolfrat stood, Who has deserved all that is good, 
And Erwin, who excelled always

Wherever one could earn great praise

And proved himself untiringly.

4360 (Indeed, no one knew better than he

How to advise an honest knight

So that his business went just right

Even to the end of his days -

One had good reason to sing his praise!)

4365 After them a wise man came

(Lupold of Milan was his name)

Who never had in his domain

Done aught to cause him any shame.

Truly, he was a well-bred knight

4370 And never boasted of his might.

A proper course he always steered.

By honest lads he had been reared

Till he was knighted with the sword.

Rother then with many a lord

4375 In Arnold's presence swore an oath

That, should the hero not be loath,

To their assistance he could look

In whatsoever he undertook.

Henceforth he lived without a care.

4380 This was the reward of the hero fair

For having given proof that day

Of his great valor in the fray.

(Just so will that man receive his meed

Who accomplishes some valiant deed.)

4385 Asprian pondered in his mind

What they should do with Constantine.

Said Grimme: "He may not survive!

In the city he must burn alive.

Now let us take his daughter dear,

4390 For whom we made this journey here,

And set the town on fire straight.

Let Widolt stand before the gate.

If anyone tries to leave that way,

How dearly he will make him pay!

4395 But if he should manage to escape,

No further action will we take."

"Upon my oath", said Asprian,

"You're going to let the city stand.

Seven apostles full of grace

4400 Once found here a resting-place, As did that very virtuous dame 
From whom the Emperor Constantine came -

Helen, who the cross did find

On which the Lord redeemed mankind.

4405 When $\mathrm{He}$ ascended from the grave,

Redemption to all those $\mathrm{He}$ gave

Whose downfall Adam brought about

Because he would not do without

That against which God had warned.

$4410 \mathrm{He}$ by whom we all were formed

Has all the world in His command.

Both the forest and the strand

$\mathrm{He}$ created and the sea

In His tremendous majesty.

4415 Whosoever serves the Lord

Can be assured of his reward.

Never will he go astray

Nor will his handiwork pass away

From eternity to eternity.

4420 And so it would seem good to me,"

Declared the giant Asprian,

"If you spared that ancient gentleman."

In the fear of God did Widolt stand.

And so henceforth throughout the land

$4425 \mathrm{He}$ was a friend of the heroes proud.

"Holy God!" he cried aloud,

"What would You have of me poor wight,

Seeing that wisdom I'm lacking quite?

As soon as my body is no more,

4430 What then lies for my soul in store?

Alas, that I was ever bred !

The Devil put it into my head

That I most miserable clown

Wanted to burn the city down.

4435 O Lord, I have sinned badly!

And yet would I right gladly

Receive Your grace before I die.

Very much afraid am I

That just as it was with my birth,

4440 So You will take me from this earth

With all my sins condemning me.

The fiery pit You did decree

For every wicked sinner here.

How very much do I revere

4445 The good Saint Michael there on high:

In him the soul has an ally. 
'Twas he who brought the Devil low.

He gave him such a mighty blow

That he fell into eternal flame.

4450 Because his pride he could not tame,

$\mathrm{He}$ was no longer allowed to be

One of that heavenly company."

The giants then did not delay:

To a man they threw their clubs away.

4455 For the sake of the Eternal Christ,

Who had given them the gift of life,

They did not harm the famous town -

Else they would surely have burned it down.

Rother bade that one should bring

4460 The faithful Lupold there to him.

He summoned the mighty Berchter too,

Who always gave him counsel true.

"O King", the latter then did say,

"Give heed to God and your soul today

4465 That honor may be yours alway.

Do not allow the town to fall.

Should Constantine be harmed at all,

Guilty of that we all shall be

And must be damned eternally.

4470 I tell you truly, master dear,

That Constantine I do revere.

Now may this profit the mighty king!

God Who fashioned everything

Punishes that man indeed

4475 Who breaks the limits $\mathrm{He}$ has decreed,

For then he leaves the proper way.

Our Savior does truly say

That whoever is bound by love to him

Must be at all times free from sin.

4480 Now, dear sir, I beg of you:

Send for your wife without more ado!"

To this the mighty king did say

In an extremely prudent way:

"Since my father ceased to be

4485 And you were put in charge of me, You have looked after my good name

With the utmost devotion, worthy thane.

You guarded me both night and day

So that no harm did come my way;

4490 And you brought me up like your own son.

(Most Christianly was all this done!) 
And you taught me too that honest knights

Should never be injured in their rights.

Now may Almighty God above,

4495 In token of His lasting love,

Reward you for your service true.

I shall not cease to mourn for you

If I survive you, worthy thane -

Nothing could cause me greater pain!"

4500 These words King Rother fully meant.

To flatter was not his intent.

At that time every hero good

Avoided sin as best he could

And only said what was in his mind

4505 About the rest of humankind -

Lest he should have to suffer shame.

The princes then were free from blame.

They dwelled in the kingdom, so we hear,

And faithfully served their master dear.

4510 Very much afraid meantime

Was the mighty Constantine.

Unto the queen he then did cry:

"Ah, dear wife, how much do I

Regret that into this world I came -

4515 By Rother's men I shall be slain!

What folly was I guilty of

That ever I snatched his wife away!

For that I now shall dearly pay.

Besides, there was no reason to;

$4520 \mathrm{He}$ always rendered service true.

And yet I wickedly essayed

To have that gentleman repayed

By letting him hang this very day.

It often happens, people say,

4525 That what a man has one time done

He meets on all sides later on.

'Twas I myself who dug this pit.

Now I shall have to lie in it

(As I deserve for my behavior)

4530 Unless I'm saved by Christ our Savior

And by His gracious mother too.

Now take my daughter along with you

And go forth with her from the town

L. $4516 \mathrm{~A}$ line is missing here. 
And before the gentleman kneel down

4535 And for the Lord's sake plead with him

To reflect upon the plight I'm in

And not deprive me of my life.

And tell him further, gracious wife,

That here in the city I shall dwell,

4540 So that till Doomsday one will tell

How much was accomplished by the man

When Rother did not let him hang."

Now hear the answer the good queen made!

"O Constantine, why be afraid?

4545 Those princes can surely be counted on

From the land of Egyptian Babylon

To help you hang the mighty king.

Perhaps you still can capture him.

'Tis pride has been your downfall!

4550 You wouldn't listen to me at all.

You treated God with the utmost scorn,

At Whose command we all were born,

And after the Devil you chose to go,

By whom in the end you've been brought low.

4555 With God you would have been better off.

The Devil will fling you into his trough

Where you and all your pals in sin

Will be able neither to wade nor swim.

From all this you can understand

4560 That there is nothing that a man

Ought to avoid on every side

More than the accursed pride,

By which the Devil has brought it about

That he has never yet run out

4565 Of "Oh me!" and "Ah me!"

And every kind of misery -

Of which he never has a lack;

And he'll give you some if you follow his track."

Constantine considered how

$4570 \mathrm{He}$ could manage it somehow

That he'd be spared by Rother's men.

This seemed to him the best plan then:

He bade his daughter visit him there,

Clad in raiment passing fair.

4575 Then women and maidens began straightway

To dress themselves in their finest array.

They put on mantles, so we're told,

Which had been trimmed with cloth of gold 
And adorned with precious jewelry,

4580 Set in gold most skilfully.

To Constantine then did repair

Eighty ladies passing fair.

Decorously they walked along.

A golden crown from each one shone.

4585 To the Hippodrome one began to lead

Many a palfrey and many a steed.

Then one could hear the tinkling tones

Of dainty pearls against precious stones

Which adorned the horses' breast-straps.

4590 The saddles were in velvet wraps

Which shone forth with a greenish hue -

In case our story tells us true.

Upon a silken covering

Was seated the daughter of the king.

4595 Constantine without his men

Rode in the midst of the ladies then.

Next to him the queen did ride;

His daughter was on his other side.

A sapphire then sent forth its light

4600 (Wherever it shone 'twas never night)

From the crown upon the maiden's hair.

Together with his daughter fair

And eighty damsels in fine array

The Emperor rode on his way

4605 From Constantinople Town

To where King Rother held the ground.

The sound of the bridles filled the air

As from the town the ladies fair

4610 Hurried forth in friendly strife.

Across the land King Rother's wife

Shone brighter than any other dame-

Just like a sapphire all aflame.

When Erwin saw them drawing nigh,

4615 Then to his master he did cry:

"Your hateful father-in-law I see!

Receive him with propriety.

Think of the honored ways of yore-

How noblemen would heretofore

4620 Forgive an injury in God's name.

Now do not put the world to shame

By the way you treat the honest knight.

Truly, it would not be right,

Seeing that the mighty lord 
4625 Comes riding here of his own accord, If you were to rob him of his life.

He is bringing you the most beautiful wife!"

Said Asprian: "'Twere well enough

4630 Then did the mighty Berchter say

In an extremely fitting way:

"O noble Asprian, speak not so!

Courtesy we all must show,

Now that he comes in the midst of these wives.

4635 And though he should have taken the lives

Of all my children, still I swear

That we ought to honor these ladies fair

By sparing the life of the mighty king -

Else great misfortune it will bring.

4640 When a man comes seeking clemency,

It is only right to hear his plea."

Then did the mighty Rother say

In an extremely proper way:

"Soldiers from the Roman land,

4645 Hearken now to my command!

Welcome Constantine the Great

In courteous fashion for my sake."

Then Berchter quickly rose from there

And went to meet the lady fair.

4650 Lupold and Erwin did the same:

They hurried forward to greet the dame.

Rother kissed his lovely wife

(She was as dear to him as his life).

$\mathrm{He}$ also kissed the ancient queen

4655 And welcomed her with courteous mien.

The valiant Wolfrat went betime

And took the hand of Constantine.

As soon as Widolt caught sight of him,

His face became exceeding grim.

$4660 \mathrm{He}$ fell to the ground and started to bite

His club with so much appetite

That flames shot forth into the sky.

What terrible looks could one espy

Upon the face of the valiant man!

4665 Near him no one dared to stand

Unless he spoke nice words to him.

He raised up there a greater din

Than hitherto he had ever made,

Whatever may have been his trade. 
4670 How rightly had the queen espied

That Widolt couldn't be pacified.

To Constantine she turned her head

And in most courteous fashion said:

"Closer to Rother you should stand!

4675 Yonder is Sir Asprian's man;

His anger no one can allay.

Supposing that this very day

You gave up your accustomed ways.

How with his club that fellow plays,

4680 So that from it the flames do fly

Higher and higher into the sky!

If it weren't for the king's good name,

Never would you see again

Either your people or your land:

4685 You would be slain by that devil's hand.

If from his chains he break away,

You will not see another day!"

The queen took the hand of her daughter fair

(She was a lady beyond compare).

4690 "Rother, master of my life,

I bring you here your lawful wife.

Take command again of her

As you think proper, gracious sir.

May God bestow His grace on you

4695 And on all these other nobles, too,

For many an honor paid to me.

You, Duke Berchter, are known to be

A hero most deserving,

In loyalty unswerving,

4700 And you serve our Lord untiringly.

Blessed must your mother be

That ever she gave birth to you!

You are an upright man and true.

Today you've shown your breeding

4705 By hearkening to our pleading

And allowing Constantine to go free,

Though he treated you so grievously."

(She spoke about the honest knight

In a manner that he merited quite.

4710 Vengefulness he had always spurned,

As from our story you have learned.)

Then did the Emperor Constantine say:

"Rother, my dear lord, I pray

That you will have Arnold brought to us. 
4715 To him I would be generous

Because of the valor with which he fought,

So that he may never lack for aught.

He hastened to rescue you, hero bold."

Then he was given a crown of gold

4720 And the right to govern his own domain:

The King of Greece he then became.

Then noblemen five thousand strong

Who at his bidding had marched along

From Constantinople so fair to see

4725 Pledged to him their fealty.

Merrily then he rode away

To his domain that very day.

There one paid him great respect,

Which the worthy hero kept

4730 Until the very day he died.

In this way he was satisfied.

If some young man were to ponder this,

It surely would not come amiss,

For if he zealously serve his lord,

4735 He can be certain of his reward.

The noblemen withdrew from there.

To Greece Count Arnold did repair.

The lovely queen then walked around

The troops assembled on that ground

4740 And kissed each one of Rother's men:

To God she commended all of them.

The valiant Wolfrat, so we're told,

With eighty thousand heroes bold

Hurried then to board a ship

4745 Which had been laden for the trip.

It brought the noble Rother home

With his fair wife across the foam.

Then into the ship the warriors pressed:

This was at Asprian's behest.

4750 Then to their homeland did repair

That company of nobles fair.

Then Constantine began to ride

Wit his good lady at his side

Back to Constantinople Town,

4755 The citadel of great renown.

His daughter's loss gave him no pain.

He now rejoiced in Rother's fame.

The ships sailed smoothly over the sea.

Rother and his company 
4760 Journeyed on across the foam And came again to the soil of Rome.

At Bari they landed on the strand.

Then horses and raiment were brought on land And all that the ships contained of worth.

4765 To Píppin then the queen gave birth

On that very day and not before

When they set foot upon the shore.

Then Lupold did not hesitate:

He hurried to King Rother straight

4770 And said "Rejoice, O worthy King!

Pleasant tidings I do bring!

What you are about to hear is true:

Your wife has borne a son to you!"

Then Rother jumped up full of glee.

4775 "O God, how thankful must I be

For the grace which You have deigned to show

To this poor sinner here below!

Now it's clear that he who cleaves to You

Will never have any cause to rue

4780 Having lost the Realm Divine:

You will sustain him all the time."

As soon as the chaplains heard this news,

Then not a minute did they lose:

They baptized at once the little tot.

4785 Pippin was the name it got.

Then many a nurse was seen to come

Into the castle on the run:

They saw that the child was carefully bred.

Later with Bertha he was wed.

4790 (She was a lady of notable worth,

Who later on to Karl gave birth.)

In view of such facts it would be wrong

To compare this with some other song,

Because it tells only what is so -

4795 Whence for it the truth does flow.

Upon his throne sat the mighty king.

Gathered there in front of him

Could be seen a mighty crowd.

Thereupon the heroes proud

4800 Began to think of traveling home,

Because each one of them had known

During the course of the campaign

Many a moment of grievous pain.

Then every man began to pray 
4805 That Rother would not say them nay

But would allow them to go their way.

The king knelt down before his men

And in God's name entreated them:

"Vassals and kinsmen, say not so!

4810 Do not think so soon to go!

Bide a while for Jesus' sake

Till recompense I'm able to make -

Else it would be the greatest shame

That to a mortal ever came

4815 Here upon this earth, I trow."

Then many a good lad answered so:

"God Almighty knows, my lord,

You've given us our just reward."

Then Asprian the giant cried:

4820 "Here in this land we must abide!

Never shall I journey hence

Until the gracious king consents."

The mighty Rother rewarded then

Every one of his doughty men,

4825 Just as honor does still demand.

He gave away the English land

To Grimme (he was a giant bold);

There he resided, so we're told,

In high esteem for many a day.

4830 To Asprian he gave away

Reims and the land that belonged thereto:

He had proved himself a vassal true.

The wealthy Scottish realm he gave

Unto the other ten giants brave.

4835 Brabant and Lothringia,

The Netherland and Frisia

Four noblemen received in fee

Who had sailed with him across the sea

In furtherance of his pursuit.

4840 (Verily, each one was a duke!)

He enriched them all with property.

Faithful had they proved to be.

Rother sat with bounteous hand

And freely parceled out his land.

4845 Many a man was enriched by him.

Spain he gave to Erwin.

Saxony and Thuringia,

The Pleissnerland and Sorbia

He awarded to ten counts that day 
4850 Who on his behalf had sailed away

With the faithful Lupold across the sea:

He rewarded them most generously.

Whoever had served him loyally

He rewarded there most royally.

4855 His treasure no one wished to share,

Nor did he offer his coursers fair.

Whosoever had proved his worth

Was paid by him with the broad earth.

Now the writer will not fail

4860 To go on telling you his tale.

It gives much pleasure to honest folk.

To the good-for-nothing it's but a joke:

Worthy deeds they have never done,

And they don't believe them of anyone.

4865 Deep in thought sat the hero good

And gave away whatever he could.

Then he did summon there to him

The worthy lord of Tengeling,

And invested him with Austria,

4870 Poland and Bohemia:

All this he was right glad to give

So that the more worthily he might live.

There never dwelled beside the sea

A noble of such high degree

4875 Either before or since that day.

Over the whole world he held sway.

Rich in land was he indeed,

And was of that true princes' breed

Who all have lived in such a way

4880 That no one ever was heard to say

That they had been false to anyone.

To a worthy end they all did come. Carefully did the noble lord

Consider whom he should reward.

4885 He summoned to him Sir Lupold then

There in the sight of all his men

And paid to the youthful knight his thanks

By making him ruler of the Franks.

To Berchter then he gave in fee

4890 Apulia and Sicily,

So that the holdings were very wide

Across which Berchter had to ride

Many a winter fully geared.

Down the ancient warrior's beard 
4895 The raindrops very often ran.

Truly, he was a dauntless man!

The nobles all requested then

Safe conduct back to their homes again.

To them Sir Asprian replied:

4900 "Why don't you all begin to ride?

If anyone is set upon,

I'll hurry to his aid anon."

The giant Widolt said thereto:

"I promise to succor all of you

4905 Who have sworn to Rother fealty:

You surely can depend on me!

Whenever I hear of someone's need,

I'll come to his aid with all possible speed."

Then Asprian's followers let it be known

4910 That they would not remain at home

If it were ever to happen again

That Rother should be needing them.

"Whoever tries to injure him

We'll tear like a chicken limb from limb!"

4915 Both to envy and to sneer

Almighty God forbade us here.

And so it was in the whole domain

As long as the mighty Rother reigned.

If one was guilty of such a sin,

4920 His life was taken away from him.

Hence it was known to every man -

Both at the court and on the land -

That whoso pledged aught to anyone

Would surely see that it was done,

4925 Provided he did not die before

Or be prevented by the law.

Rother honored with a kiss -

What pleasure he derived from this! -

Many a worthy man that day.

4930 Then they saddled the horses without delay.

Back to their homelands once again.

Then before the king there rode a knight

Upon a courser shining bright.

In gleaming armor he rode his way,

L. 4914 Several lines seem to have been omitted here.

L. $4930 \mathrm{~A}$ line is missing here. 
4935 Well-equipped for any fray.

Upon his legs the hero bold

Was wearing greaves encased in gold,

In which there had been set with skill

Gems to make them fairer still.

4940 Upon his shield there could be seen

An animal with a playful mien.

It had been wrought of the finest gold

And looked like a dragon, so we're told.

And set around it in artful wise

4945 Were stones both great and small in size

Which cast abroad a radiant light

Like stars a-shining in the night.

All around the shield's rim

Precious sapphires were set in.

4950 Upon the hero's saddle-bow

Golden swans stood in a row.

Upon his helmet was a stone

Which at the hour of midnight shone

In such a very dazzling way

4955 That one might think it was bright day.

(Alexander, the mighty man,

Had brought it back from a foreign land

Where Christian folk had never been

Either before or after him.)

4960 The stone was named Claugestian;

It adorned the helm of an ancient man.

His beard was very long indeed.

How fearlessly he rode his steed!

It galloped for him, in very truth,

4965 Better than for any youth.

Rother bade the knight farewell.

It was Duke Berchter, so we hear tell,

For the sake of whom his wife so dear

Had shed at home full many a tear.

4970 (Later at our Lord's command

He came home safely to his land.)

As soon as Berchter did receive

The king's permission for him to leave,

Then off he rode with a mighty throng.

4975 They raised their voices high in song

As on their steeds they rode along.

Many a lady had to stare

As they went riding away from there.

Rother hated to see them go. 
4980 "Ah, how heavy is this blow! Assurance to the world I give That just as long as I shall live, My pleasure it will be to share Like the eagle of the air -

4985 All that I possess of treasure With rich and poor in equal measure, Whenever it is asked of me And one shall seek it honorably As long as a loaf is mine to spend."

4990 Asprian and Widolt then Along with Rother's other men Journeyed homeward once again. An honest course they did pursue, Esteemed by everyone - that is true!

4995 The years that passed were twenty-two. By then had Pippin become a man So that he was fit to rule the land. Truly, the noble Rother had Very honestly reared the lad -

5000 Just as today still many a man Raises his son as best he can.

Rother dwelled in his domain (The Lord had spared him every pain) And raised the youthful Pippin

5005 (He was a son most dear to him) In splendid fashion, so we're told, Till he was twenty-four years old. Thereupon the youth implored That he be knighted with the sword.

5010 At Aachen then one did convoke A great assembly of the folk, To which full many a worthy knight Came as splendidly as he might. They rode to the court from far and near,

5015 Each in the company of his peer.

To the court there rode full many a lord The time that Pippin received the sword.

Thither came Sir Asprian

Along with Widolt, the valiant man.

5020 The hero Grimme came there too (He belonged to the giants' retinue

L. 4984 the eagle - a symbol of generosity; it was supposed to leave some of its prey for other birds to devour. 
And was indeed a gruesome lad.)

Attending him Sir Asprian had

Warriors seven hundred strong.

5025 They carried iron clubs along.

Then at the head of a handsome band

There rode across the Frankish land

To Rother's court a valiant youth.

'Twas Wolfrat of Tengeling, in truth,

5030 Leading doughty warriors there.

Thirty thousand heroes fair

Traveled under his command

For the assembly of the land.

From the land of Spain did Erwin ride

5035 With Master Lupold at his side.

Both were men of high degree

And traveled with propriety.

The faithful Lupold led, we're told,

Sixty thousand heroes bold

5040 From the kingdom of the Franks

That he might merit Pippin's thanks.

Ah, how Rother rejoiced aloud

When he caught sight of these heroes proud.

At Aachen they stayed overnight

5045 Until the morning showed its light.

As soon as the day began to break,

Upon his horse was seen to wait

The youthful Pippin, a hero bold,

Splendidly adorned with gold.

5050 The coursers started galloping then

Underneath the youthful men.

Into the melee rode many a lord

The time that Pippin received the sword.

Widolt and Grimme began to race

5055 All around the ring apace.

Such a noise did the giants make

That all the ground began to shake.

At Aachen then the feast went on

Until three days had come and gone.

5060 Homeward then prepared to fare

All who had assembled there.

Then Pippin vowed to every man

That he would confirm him in his land

After the mighty Rother died

5065

And he ruled over the countryside.

The festival had reached an end. 
Then every man began to wend Homeward to his own domain. There they resided free from blame.

5070 The noble Rother spent his days

In a way that earned him the highest praise.

As soon as Pippin, the youthful lord,

Had been presented with the sword

There in the Emperor Rother's sight,

$5075 \mathrm{He}$ rode through the land with many a knight

And judged according to the law

Lord and vassal as heretofore.

So at Aachen did disband

The great assembly of the land.

5080 Across the land came hurrying there

A warrior with snow-white hair -

For which old age must take the blame.

Riding close behind him came

Two thousand heroes unafeared.

5085 Around his ears had all been sheared

The noble hair upon his head.

In all respects he had been bred

To be the very truest man

Who ever served at a king's right hand.

5090 To Aachen he had set out riding

As soon as he received the tiding.

His horse's reins he firmly grasped.

How very little time elapsed

Ere Rother caught a glimpse of him!

5095 Now hear the words of the mighty king:

"In truth, I am a happy man:

Here comes the hero of Meran!

Welcome him with courteous mien."

"I'll gladly do so," said the queen.

5100 Verily, she was not remiss:

She honored the good duke with a kiss

The noble Rother could hardly wait

Till Berchter had ridden through the gate.

With his very own hand he held his steed:

5105 The hero had merited this indeed!

Then Rother's followers did the same:

They saluted those who with Berchter came.

In this way did the honest men

Only do what befitted them,

5110 Because the valiant hero had

Proved himself a valiant lad 
When he had still been in his prime And had ridden to battle many a time. As soon as the noble duke had heard

5115. Everything that had occurred, Then he began without more ado To counsel Rother what to do. "Join with me, $\mathrm{O}$ worthy man, In the execution of my plan

5120 And help thereby your wretched soul Of an honest life that is the goal.

My lord, your hair is turning grey. Everything must pass away. All good men it does become,

5125 When their life is almost done, To make their peace with God on high Before the hour when they must die. Here in the world you won much fame. Of my companions there once came

5130 Sixteen to a rendezvous And considered what they ought to do. They shed, dear master, many a tear Because for your father the end was near. In Death's grip lay the hero true

5135 And bade that I look after you.

Since then I've never left your side, So that nobody ever tried To do you any injury

Without at the same time threatening me.

5140 What I say now, dear sir, is true:

I can only be of help to you

If to my counsel you pay heed.

In that event you will be freed

Forevermore of every dole -

5145 And you will benefit your soul!"

The mighty king sat silent then.

Berchter spoke to him again:

"Noble lord, my words are true:

It's good advice I'm offering you.

5150 Deserve of the saints their mediation.

Wealth is an abomination!

Here on earth it is unclean;

In our heavenly home it can't be seen.

However much a man may win,

5155 How quickly it gets away from him As we can notice every day. 
Follow my advice, I pray,

And help your wretched soul thereby,

That it may live and never die.

5160 There is no need to be distressed.

Whosoever has been blessed

With the grace of Christ our Heavenly King

Will cherish it more than anything.

There was no limit to your might.

5165 For you went everything just right.

What does that come to anyhow?

If someone should surpass you now,

To him you then must needs defer.

Now heed my counsel, gracious sir:

5170 Let us both to Fulda wend.

Whoever seeks a blessed end

May gladly don there monks' attire.

Let both of us be monks, dear sire!

To our poor souls we must pay heed.

5175 Inconstant is this life we lead!"

Then answered him the worthy king

That he would gladly do this thing.

Rother did not linger there:

He hurried to his lady fair

5180 And told her what he meant to dọ.

The goodly queen replied thereto:

"Berchter never has, I vow,

Counseled better than he has now.

O noble Rother, do his will!

5185 It surely will not turn out ill."

Then said the

Just as it still today does stand,

So that it is honored throughout the land.

Then from the world the queen withdrew,

5190 As God Almighty inspired her to.

Then throughout all the Roman land

Peace prevailed on every hand

Until King Pippin passed away

And over the empire Karl held sway.

5195 A splendid lord he proved to be,

And he ruled the land most prudently.

Now to an end our tale has come.

Fold your hands now everyone

L. 5186 A number of lines have been omitted here. 
And pray to Almighty God on high, 5200 Who fashioned us to live and die, That to the poet He show His grace And keep you also 



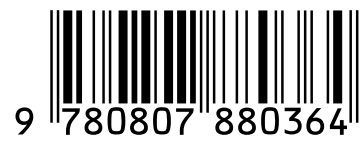

